\title{
Transitions from higher education to work
}

\author{
A briefing paper prepared by Lee Harvey (Centre for Research and Evaluation, \\ Sheffield Hallam University), with advice from ESECT and LTSN Generic Centre \\ colleagues.
}

(C) Lee Harvey and contributors, February 2003

\section{The Perspectives series of employability briefing papers}

This set of five papers examines the relationship between employability and higher education. Together they constitute a ground-clearing exercise, summarising some of the key themes in employability as seen from less-than-common perspectives. They will shortly be followed by the Employability Issues for ... series, which will brief seven key audiences — for example, employer groups, students, LTSN subject centres - on ways of enhancing student employability in HE. This set of five is complemented by another five papers published early in 2003 by the UK Learning and Teaching Support Network (LTSN) Generic Centre (GC) in its Learning and Employability series.

Four of the papers in this Perspectives series explore major employability issues as they bear upon different phases in the student life-cycle - one looks at how schooling, further education and other experiences prepare students for higher education; one at the first year or level 1 experience; one at the student experience, particularly at levels 2 and 3; and this, the fourth, at transitions to work. The fifth scans international work on employability the better to inform thinking about what we do in England, Northern Ireland, Wales and Scotland ${ }^{1}$.

This, the fourth paper in the Perspectives series, refreshes our thinking about employability in higher education by considering students' transitions to work. It is long because planning for good transitions means thinking about the whole undergraduate experience - also addressed by Perspectives 2 and Perspectives 3 - as well as looking at recruitment practices, self-presentation and the graduate labour market. Lee decided to go over some of the ground covered by others in the Perspectives series in order to treat transitions in a comprehensive fashion, rather than be less helpful by concentrating only on the job seeking process and early months in the workplace.

There are many conclusions that can be drawn from Lee Harvey's work:

- Employability is about developing a range of attributes and abilities, not just job-getting skills.

- Employability is not something distinct from learning and pedagogy but grows out of good learning.

- What employers are looking for are flexible graduates who can add value when necessary but can also help transform the organisation in the face of change.

1 Although the GC has a UK-wide remit, ESECT, which has prepared this paper, is charged with employability in England alone, which is why the analysis is couched in terms of English pre-HE experiences, which are in some ways different from those elsewhere in the UK. 
- Higher education is rapidly developing an array of approaches for explicitly enhancing the employability of their students.

- Increasingly higher education institutions are developing an integrated, strategic approach to employability issues. 


\section{Introduction}

The higher-education to work interface is at the epicentre of current debates about employability in the UK. In essence the debate is about what employers want and what higher education institutions can do to enhance the employability of students. Much of the focus has been on the employability of full-time undergraduates. However, part-time undergraduate, taught postgraduate and continuous professional development courses should not be neglected (although the main focus of this paper is undergraduates).

\section{Defining employability}

Employability is a contentious concept, with a plethora of micro-interpretations. Many of them variants on defining employability as the propensity for graduates to secure a job and progress in their career. For example, the University of Newcastle (Allison et al., 2002) defines employability as the 'capacity to move self-sufficiently into and within the labour market, to fulfil potential through sustainable employment'. The Learning and Employability Series of papers being produced by the Learning and Teaching Support Network (LTSN) Generic Centre (2003) define employability as 'a set of achievements, understanding and personal attributes that make individuals more likely to gain employment and be successful in their chosen occupations'. Summaries of different definitions can be found in Harvey (2001) and Lees, (2002b).

A note of caution needs to be struck. Employability is not just about getting a job. Conversely, just because a student is on a vocational course does not mean that somehow employability is automatic. ${ }^{2}$ Employability is more than about developing attributes, techniques or experience just to enable a student to get a job, or to progress within a current career. It is about learning and the emphasis is less on 'employ' and more on 'ability'. In essence, the emphasis is on developing critical, reflective abilities, with a view to empowering and enhancing the learner. Employment is a by-product of this enabling process (Harvey, 2003; Lees, 2002b; Knight \& Yorke, 2002).

\section{Seeing employability as a process}

The relationship between graduate, institution and employer is not simple. It depends on the way in which graduates have engaged with employability development opportunities provided by institutions, be they central support services, experiences embedded in the curriculum, work experience or opportunities to reflect on and record experience. The pedagogical processes and reflection on and articulation of learning are essential elements that are mediated by subject discipline and external factors, not least the extra-curricular experience of graduates and, ultimately, the recruitment practices of employers (Figure 1).

2 Joan Newton, Anglia Polytechnic University, points out that 'Too many academics assume [mistakenly] that because a student is doing a vocational course, employability is automatic'. 


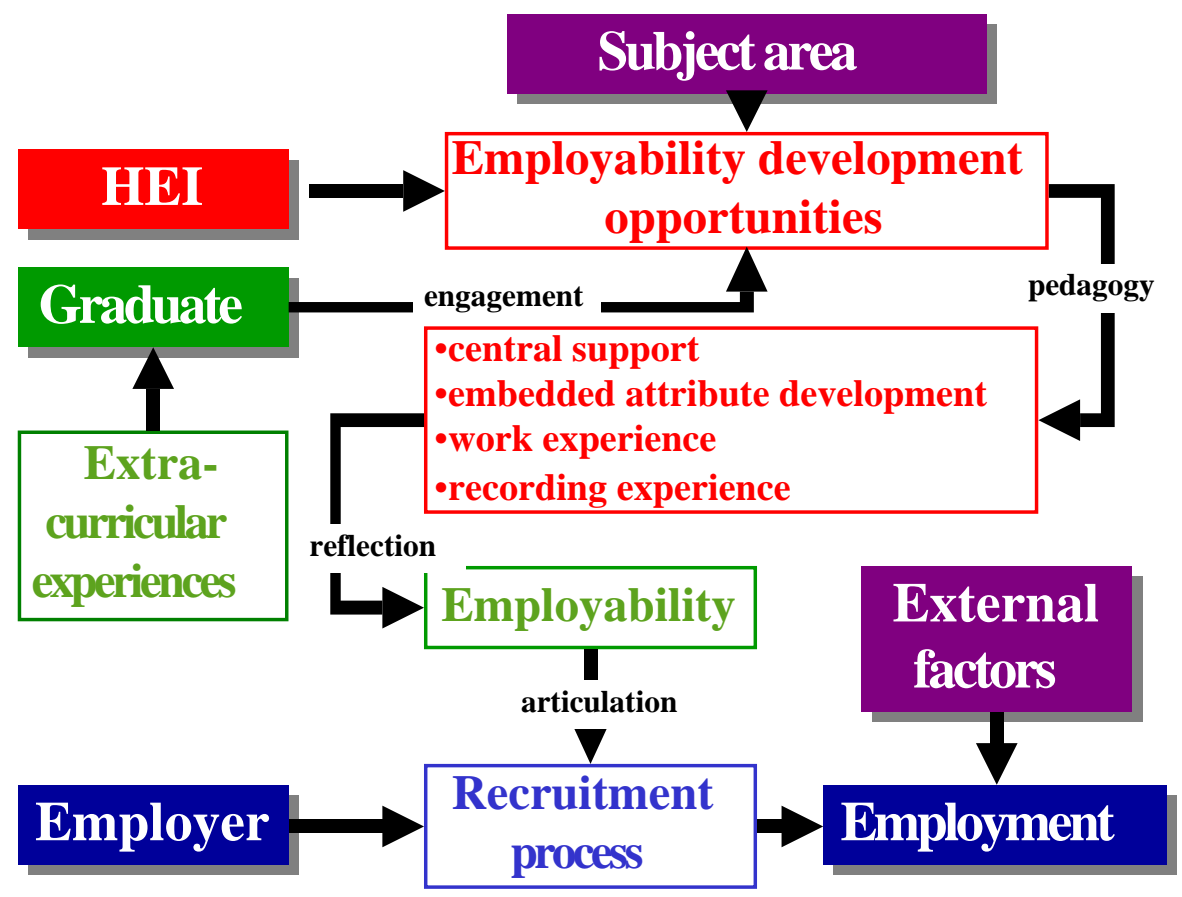

Source: Adapted from Harvey et al., 2002.

Figure 1: A model of graduate employability development

\section{Transitions}

Interviews done by the Skills plus project ${ }^{3}$ found employers of recent graduates to be quite satisfied with them once they had six months or so to their credit, which is consistent with unpublished research findings from a University of London team that the impact of employability development may be greatest in the first few months of graduates' careers smoothing them through the transition. Lees (2002b, p. 3) comments that 'it is possible that employers' criticisms of the shortcomings of graduate recruits are not so much the result of failure in the HE curriculum, rather of failure in the transfer process'.

Transitions do tend to be hard. There is no claim here that transitions can be made Teflonsmooth but there is a claim that higher education can help students to prepare better for transition to the workplace.

\footnotetext{
3 This project, funded by the English Department for Education and Skills, based in North-west England, entailed (a) working with 17 subject departments in four universities to enhance their contributions to undergraduate skills development (b) research with 97 new graduate hires and their co-workers or immediate supervisors to see what employability meant in practice (c) a pilot study with ten unemployed recent graduates (d) an investigation of the efficacy beliefs of over 200 first and final year undergraduates. This two-year project finished in 2002. No continuation funds could be found.
} 


\section{Employer views and recruitment practices}

There is an explicit assumption, embedded in the employability agenda and the shift towards fees, that higher education is about preparing graduates for the world of work. This view gained increasing currency during the 1990s to the extent that in 1996 the Council for Industry and Higher Education declared:

Most British people, most educators and most students now believe that it is one of higher education's purposes to prepare students well for working-life. (CIHE, 1996)

However, there continues to be a concern expressed by employers that higher education is not good at producing work-ready graduates. Over the last quarter of a century this has become almost a mantra for some employers

\section{Preparation for work}

Studies in the 1990s and earlier showed that although employers consider an undergraduate experience to be beneficial, they doubted its efficacy as a preparation for work. Younger, fulltime students, other than those who have had a significant placement experience on their course, often leave university with little idea of the nature and culture of the workplace and find it initially difficult to adjust. This period of adjustment - the time it takes for a graduate to become effective in the workplace - is a cost that graduate employers are no longer able or willing to bear. This means that higher education programmes are expected to better prepare graduates for workplace culture.

Despite the renewed focus on employability over the last five years, considerable changes in curricula and enhanced support for students and graduates, there remains discontent among some employers. De la Harpe et al. (2000) suggest that there is concern world-wide that existing undergraduate programmes are not producing graduates with appropriate life-long learning skills necessary for their careers. A recent article in the Times Higher Educational Supplement perpetuated the view: 'There is a chasm between what industry wants and what universities provide' (Medhat, 2003). Such views tend to be vocal, if misleading, the actual nature of the 'chasm', as in this case, is rarely spelled out.

There is, though, no single employer view (Cannon, 1986). While there is much agreement about many aspects of higher education, the heterogeneity of commerce and industry needs to be kept firmly in mind. Furthermore, there is often not a single view within an organisation. Line managers, graduate recruiters and strategic managers may express different expectations of graduates (Harvey et al., 1997). Often, those who are most critical of graduates, those who operate in the public forum, are highly placed in the organisation and have the least contact with new recruits.

\section{The relevance of higher education learning}

There is, though, a lack of research into the extent to which knowledge learned on a programme of study is used in a job (Teichler, 1998). Available evidence, much of it anecdotal, is that apart from some professional practice areas, little of the 'knowledge' is applied in job settings. Thus, employers are more concerned about a variety of personal and interpersonal skills and abilities than they are job-related knowledge. This is a growing trend in many Western countries, marked in the UK, where there is a high proportion of nonsubject-specific recruitment. Even in professional areas such as engineering and medicine, it 
is not so much the knowledge from the programme that is important to employers but whether the student has grasped the underlying principles (Harvey et al., 1997).

\section{Education not training}

Despite concerns that some graduates are not work-ready, employers repeatedly say that they do not want 'trained' recruits. They want intelligent, rounded people who have a depth of understanding, can apply themselves, take responsibility and develop their role in the organisation. Employers want graduate recruits who are educated and can demonstrate a wide range of attributes, not least the traditional high-level academic abilities of analysis, reflection, critique and synthesis. Employers do not want graduates trained for a job, not least because jobs change rapidly. Although they may want new recruits to add value rapidly, employers wanted graduates because they can potentially do more than add value.

There are fewer graduates going into graduate recruitment programmes that induct and train new employees. Where these programmes exist they tend to be shorter than there were a decade ago. Employers rarely have the time for a leisurely induction process and a significant number of larger organisations are moving away from 'fast-track' introductory training to more job-specific recruitment requiring more rapid effectiveness. Many small and medium-sized organisations want new recruits to be effective from the outset. It is likely that there will be increasing pressure on graduates to 'get up to speed' quickly.

Successful transition from higher education to work arguably requires 'practical intelligence' (Sternberg and colleagues, 2000) that requires the use of tacit knowledge. This is,

the procedural knowledge one learns in everyday life that is usually not taught and often is not even verbalized. Tacit knowledge includes things like knowing what to say to whom, knowing when to say it, and knowing how to say it for maximum effect (Sternberg and colleagues, 2000 p. ix).

Tacit knowledge is even more important given the changing nature of employer organisations over the last twenty years. Organisational structure, focus, objectives and strategies have changed and are likely to continue to change. Changes have been prompted by the continuing information revolution, by a growing awareness of the need to be responsive to customers, clients and other stakeholders, and by the need to adopt an international perspective. Organisational change has embraced delayering, downsizing and outsourcing, as well as decentralisation and re-centralisation, break-ups and mergers. Underlying all this is the need for organisations to be flexible. This has put in doubt the notion of a 'job for life'.

The end of the 'job for life' may not apply in areas such as medicine, health, teaching and law, where, once established, graduates rarely face redundancy. In many areas, though, graduates are as vulnerable, as any other recruit, to the vicissitudes of change. Even in 'safe' occupations, there is a continuous need for professional updating and development. Thus, graduates should no longer expect stability and a linear career progression but they should expect that education and training will continue throughout their working lives. They may also have to take responsibility for initiating their own development, as many of the Skills plus informants said ${ }^{4}$.

Furthermore, graduates need to be alert to the growing and varied range of graduate opportunities, often in non-traditional areas (CSU, 2003). Graduates are being employed in areas that were formerly staffed by non-graduates. However, the jobs are not the same; they are evolving over time and the expectation is that this will continue. There is a symbiosis between the changing nature of jobs as a result of organisational change (delayering, for example, requiring a wider range of job functions and communication involving a broader range of people) and the abilities, desire and enthusiasm of graduates to 'grow' jobs.

\footnotetext{
${ }^{4}$ These data have not yet been published but will be summarized in Knight and Yorke (2004)
} 


\section{Graduates are cost effective}

Despite the premium salaries and often-voiced reservations about graduates' abilities, employers consider that graduates are cost-effective and that a degree education is both beneficial for the graduates as well as adding value to the organisation.

Among graduate-level recruiters, there has been relatively little interest in alternatives to the current degree education; indeed, in some cases little interest in anything apart from the traditional A-level to degree route. There is, though, growing concern that the education system does not produce enough skilled technicians, which the Foundation Degree initiative, in part, attempts to address.

Employers in the UK tend to the view that, for young people, an extended period away from home helps them become mature, develop a broader perspective, enhance interpersonal skills and self-confidence and generally assists them to become 'a more rounded person'. These self-sufficient dispositions, developed in a university setting, is with a wider range of people) and in the future global economy where it will be necessary to be sensitive to cultural sensibilities and local politics. However, the growing numbers of non-traditional students, and the rising cost of going to university does not sit well with this presumption.

\section{Paying for the benefit}

Although employers see graduates as cost effective, there is increasing pressure for graduates to shoulder more of the costs of their education. Not only is higher education expected to be relevant to the world of work, the principal argument in favour of the introduction of fees has been the additional financial benefit to be gained from obtaining a degree. Indeed, with AGR members expecting on average to pay graduates $£ 20000$ starting salary (AGR, 2003) ${ }^{5}$, graduates do appear to be advantaged. However, that only tells part of the story. Since the late 1980s, British government and the EU have consistently promoted the need for a better-educated workforce to develop the knowledge economy. Indeed, the rhetoric has been about a better-educated citizenry, which ultimately benefits everyone. In Britain, this social good, is not to be achieved through taxation but by making those who forfeit years of earning to undertake higher education pay for the subsequent benefit, over and above the taxes that their higher income generates.

There has also been a backlash to the widening participation agenda, with the reactionary right claiming that Britain is producing 'too many graduates'. This clearly goes against the aim of a better educated-citizenry. Whether this reactionary view is born out of middle-class elitism or is the result of aligning graduate production with some mythical notion of what constitutes available graduate jobs, is a moot point. To assume a link between economic requirements (or planning) and the 'production of graduates', misses the point that Britain needs a better educated citizenry, not a citizenry trained for specific jobs. That graduates 'grow' jobs makes this matching notion obsolete, as AGR has often pointed out. The latest legitimation for curtailing the numbers of graduates is because there is an apparent shortage of skilled artisans - plumbers, welders and so on. Instead of taking up a 'trade', students are opting for degrees. The foundation degree addresses this issue and is a more appropriate approach than artificially capping the numbers of people who have experienced higher education.

5 AGR members tend to be large organisations and mostly in the private sector. They tend not to include recruiters of health, education and art and design graduates. The high starting salaries shown in AGR surveys are dominated by the financial sector. 
There may, though, be a problem of aligning graduate expectations with outcomes graduates may expect to be able to get a reasonable job at a salary that makes their investment in higher education economically, as well as intellectually and culturally, worthwhile. Increasing fees and greater student debt will raise significant questions for graduates, especially from non-traditional students, whom the government is trying to encourage.

\section{A skills gap}

Analytic studies of the labour market have suggested that there is a skills gap between the labour requirements of industrially developed societies and the outputs from the education system (O'Leary, 1981; Lindley, 1981; Teichler, 1989; TUC, 1989; PSI, 1990; IoD, 1991; Khawaja, 1991; AGR, 1995; FSW, 1998; EG, 1998).

For example, the Welsh Development Agency in partnership with eleven other agencies, and supported by the European Social Fund, undertook a future skills needs study for Wales. The study explored the extent of skills shortages, usually from the employers' point of view, and made tentative suggestions about overcoming them (FSW, 1998).

Similarly, Ireland's success in the 1990s in attracting overseas electronic companies has put pressure on Ireland's supply of certain skills. The Irish government announced a new business, education and training partnership in late 1997 to develop national strategies to tackle the issue of skill needs, manpower estimating and education and training for business. An expert group on future skills needs $(E G, 1998)$ produced an initial report focussing on technology and estimated an annual skills gap, over the next few years, of 2200 technologists (64\% at the level of technician and $36 \%$ at degree or professional level). The aim was to find ways, in the short-term, to attract, upgrade or retrain people to fill this gap. The time lag is such that the restructuring of higher education would not produce suitably qualified people quickly enough. Since then, the Irish economy, like many others worldwide has slowed down.

Reports based on analyses of skills shortages are endorsed by anecdotal accounts and through the voice of pressure groups, especially of large graduate recruiters, such as the surveys undertaken by the Association of Graduate Recruiters. However, the identification of skills gaps is not as straightforward as it may appear. There are analytic, communicative and perceptual problems associated with identifying skills gaps. .

Communicative and perceptual problems (Harvey with Green, 1994) include:

- A view that education is a 'once-and-for-all' activity, which ignores the need for life-long learning and skills updating.

- A lack of communication between higher education and commerce and industry;

- Indifference and inconsistency of industrialists in identifying what they want (cannon, 1986; Davies, 1993);

- The perceived threat to academic autonomy and freedom posed by closer links to commerce and industry

The main analytic problem is to distinguish between processural and structural shortages. The former reflects the inability to match the people with skills to the available vacancies. The latter is more problematic and refers to a gap between the requirements of industry and commerce and the available skills in the economy. Analysing the extent of a structural skills gap is difficult for four reasons: 
- Identifying the economic unit of analysis: locality, region, country, or European community;

- Identifying the sum of available skills;

- Identifying individual and hence summative requirements: being clear whether structural skills gaps are the result of missing individual skills or missing skill combinations. (For example, there are plenty of graduates with good ICT skills but poor teamworking or communication skills);

- Identifying transformational needs: often employers are unaware of what skills they need to help them transform and thus organisations become trapped into adapting their requirements to the skill level of the available people (FSW, 1998, p. 105);

- Identifying and specifying the difference between the 'expressed requirements' skills gap and the 'latent needs' skills gap.

Studies of skills gaps in the past led to various attempts at planning educational provision to match projected skills shortages (Pearson, 1976; DE, 1981; IMS, 1981; Fulton, Gordon \& Williams, 1982) but rapid change resulted in forecasts being inexact. Current thinking is tending to revert back into the cycle of identification and changing supply. However, this process, even if it includes accurate analysis and prediction, is far too cumbersome and takes too long; between 5-10 years for any noticeable affect. By that time the requirements have moved on. Chasing the ideal skill-balance in this way, although periodically popular, is a misconceived strategy.

An alternative is to look at the relationship between skill, knowledge acquisition and economic performance. This is the aim of the centre on Skills, Knowledge and Organisational Performance (SKOPE, 2003), which is based jointly at the universities of Oxford and Warwick but also includes scholars from other institutions. It examines the relationship between the supply, demand and use of skills and knowledge addressing the links between education and the world of work; economic outcomes for individuals, organisations and society and the effectiveness of various policy and institutional interventions by external agencies. Its close empirical work puts discussions about skills shortages and gaps on a more secure basis than some of the opinions that get prominent media attention. The SKOPE web site lists over 40 papers on skills and training that are obtainable on request.

That said, it is arguably far more important to educate a flexible, empowered labour force than to place too much faith in education's ability to anticipate the diverse, fast-changing needs of the different economic sectors.

\section{The criteria employers use when recruiting graduates}

Employers want recruits who are going to be effective in a changing world. They want people who can deal with change - indeed who thrive on it. They want intelligent, flexible adaptable employees who are quick to learn. Graduates are much more likely than non-graduates to meet these criteria. In a world of uncertainty employers want people who are able to work on a range of tasks simultaneously. They do not need people who are resistant to new approaches or who are slow to respond to cues. However, there is evidence, presented in this section, that employers do not always, in practice, use the best criteria and follow the best recruitment processes. It is important that students appreciate this, especially those most likely to find themselves at a disadvantage in the labour market. Brennan and Shah (2002) allude to work being done in some universities and colleges to help such students present themselves to best advantage in recruitment processes. 
There is a significant body of research, which spans the last 20 years, into the criteria that employers use when recruiting graduates (Fergus, 1981; Caswell, 1983; Gordon, 1983; Wingrove \& Herriot, 1984a, 1984b; Richardson, 1989; Green, S., 1990; Harvey, Burrows \& Green, 1992, CBC, 1992, 2000; Binks, Grant \& Exley, 1993; NBEET, 1992; Johnson, PereVergé \& Hanage, 1993; Harvey with Green, 1994; Phillips-Kerr, 1991; BT, 1993; Brennan et al., 1996; FSW, 1998; Dunne et al., 2000).

Mostly, this provides various lists of skills and abilities that employers want from graduates. A recent synthesis can be found in a paper by Lees, (2002b) and Harvey and Green (1994) provide a composite skills list based on various earlier studies, which they contrast to their own research outcomes. Little (2003) provides some international comparisons.

There is considerable agreement about a core set of desirable skills, often independent of the degree subject. This has changed remarkably little over 20 years, apart from the rise of IT skills. In addition there tend to be organisation-specific requirements. However, employers each have their own variant and there is unlikely to be complete agreement even within an organisation (Cannon, 1986; Mansergh, 1990; Burrows, Harvey and Green, 1992; Harvey et al., 1997). Previous research has suggested that there are likely to be differences in views between manufacturing and service industries and government agencies. The size of employer organisations is also likely to have an impact on views. Furthermore, there may be differences in attitude depending on whether or not the managers are graduates (Cannon, 1986; Burrows, Harvey and Green, 1992; Johnson, Pere-Vergé and Hanage, 1993; Johnson and Pere-Vergé, 1993).

In this skills language, the core set consists of interactive attributes - communication skills, interpersonal skills and team working - and personal attributes. Personal attributes include, intellect and problem solving, analytic, critical and reflective ability, willingness to learn and continue learning, flexibility and adaptability, risk-taking and self-skills In short, attributes that help organisations deal with change. An understanding of the world of work, some commercial awareness and appreciation of work culture are often desirable attributes. In some cases, subject knowledge and understanding are desirable, as are specific technical skills. However, more often than not, subject knowledge is often not high on the list of desirable attributes. A decade ago, Employer Satisfaction revealed the low importance placed on subject knowledge overall, with over a third (38\%) who said it was of little or no importance (Harvey and Green, 1994). At the time, this caused considerable concern but is now more readily accepted in the UK.

The 1990s was characterised by approaches that sought ways to develop skills, especially the 'key skills' first identified by the CBI and then re-launched by the Dearing Report (NCIHE, 1997). The Skills Task Force (1998), for example, claimed that 'the lack of skills among graduates and young people is a key concern for employers'. The DfEE Higher Education Projects Fund, 1998-2000, included projects funded to 'develop strategies to ensure all learners had the opportunity to develop Key Skills, employment skills and transferable skills' (DfEE 1999, p. 2). As the projects developed, initial concern about the place of skills in the curriculum moved on to exploring where students might develop skills, how they might be assessed and how skills link to the work environment (DfEE, 2000).

Some employers have gone beyond the compilation of lists of desirable attributes to examine how these attributes enable graduates to be effective at work. Graduates' Work (Harvey et al., 1997 ) is one of the few studies hat moved from the identification of attributes to the exploration of the relationship of attributes to roles that graduates will play in a flexible organisation. Graduates play different roles in different settings and it is important that they have the attributes to know when to fit into the work place and do the job, when to take risks and persuade people of the merit of new ideas and when to think laterally, take initiative and responsibility and move the organisation forward. 
The Graduates' Work study identified a continuum of graduate employment to which new recruits need to adjust. At one end, in the dynamic changing organisation, graduates need to be adaptive, that is, they need to be able to rapidly assimilate, 'fit in' to the workplace culture, work in teams, exhibit good interpersonal skills, communicate well, take on responsibility for an area of work, and perform efficiently and effectively to add value to the organisation.

However, employers want more than that, they also want employees who can use their abilities and skills to evolve the organisation. They want people who exhibit an ability to learn and add to knowledge and skill and the ability to use their knowledge and skills in the face of change. They want people who have bright ideas, who are able to communicate them to others, develop them in teams and persuade colleagues to attempt new approaches: adaptable people.

Ultimately, employers say that they are looking for people who can do more than respond to change. They want people to anticipate and lead change, to help them transform their organisations. People who can use higher-level skills, such as analysis, critique, synthesis, and multi-layered communication to facilitate innovative teamwork: transformative employees.

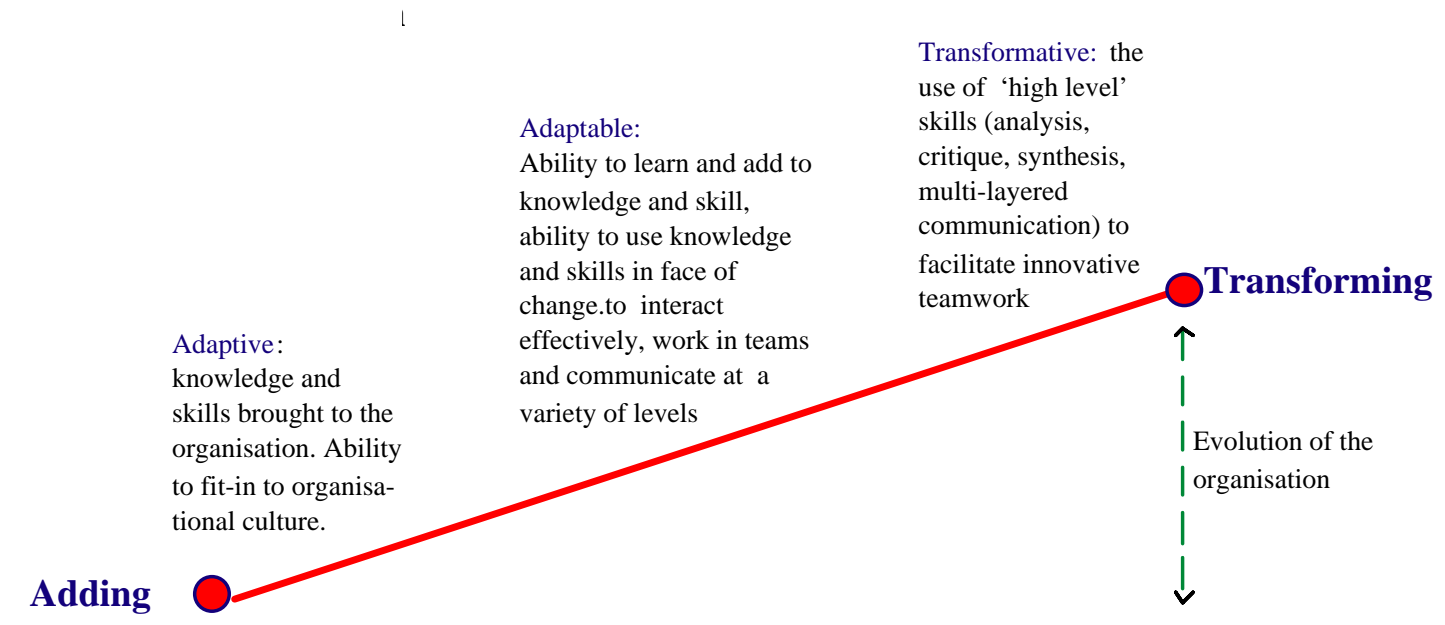

Adapted from Harvey with Green, 1994, p. 16

Figure 2: Employability continuum

Although employers want adaptive, adaptable and transformative people, these are not distinct types of employees. All employees, in different contexts, need to be adaptive, adaptable and transformative. It may be that in certain circumstances there is more emphasis on the 'fitting in' and a 'doing the job' while in other situations, employees are expected to spend a lot of time motivating themselves and others to innovate and reconceptualise ways of working. Organisations are unlikely to expect graduate-level employees either to merely 'fit in' or, conversely, to be constantly 'transforming'. Tacit knowledge is important in being effective at moving along the employability continuum, from adaptation to successfully shaping one's environment. 'Experience in a particular domain is important in the acquisition of tacit knowledge' (Sternberg and colleagues, 2000, p. 223).

The adaptive-adaptable-transformative continuum is cumulative. Employees cannot be effective at the transformative end of the continuum unless they also have the skills and 
abilities to add value. Someone who attempts to be merely 'transformative' without adding is likely to be working alone and failing to harness the transformative potential to organisational culture and structures. In essence, 'transformation ability' without added value is likely to be destructive rather than transformative. For instance,

... despite the different emphasis on skills and abilities, ranging from the imitative to the iconoclastic, the difference between adding value and transforming is not primarily a different set of skills but the difference between having abilities and putting them into practice. It is about the way a range of skills and abilities are applied. It is the difference between fitting into a team, working in a team, and getting the team to push the boundaries. It is the difference between adding value by bringing knowledge to a situation and reconceptualising by asking appropriate questions. It is the difference between having the interpersonal skills to get on with clients, customers, colleagues and using interpersonal skills to 'include' a range of stakeholders. (Harvey et al., 1997, p. v)

Graduate status itself is no guarantee that the employee will be adaptive or transformative. In a sense, graduate status adds some immediate value through knowledge and higher-level skills such as analysis. However there may be counter tendencies that reduce the value or at least delay it: viz. failure to understand organisational culture, commercial pressures, or lack of prior opportunity to put theory into practice.

There is then a potential clash between the need for adaptive employees and the underlying requirement for people who can deal with and, preferably, lead change. This poses a dilemma for an organisation. To what extent should it employ adaptive people who may rapidly add value to the organisation and to what extent should they risk employing people who may help transform the organisation?

\section{Work experience and recruitment processes}

Employers tend to be favourably disposed to work experience as something that helps students prepare for rapid effectiveness. Work experience provides a foretaste of workplace culture as well as contributing to learning. There is a growing trend to recruiting from students who have undertaken work placement with companies. Studies ${ }^{6}$ have shown that employers from large and small organisations think work experience helps students develop desirable attributes. Indeed, many employers would encourage all programmes to include some form of work experience. However, there is still a considerable shortfall in work experience opportunities provided by employers, which is associated, perhaps, with a growing interest in work-related learning where direct work-based learning is not available.

That said, employers' positive view of work experience is supported by a statistical analysis of first-destination employment returns, provided by the Higher Education Statistics Agency (HESA), for all full-time degree qualifiers from all higher education institutions in the United Kingdom in 1995-96 (Bowes and Harvey, 2000). ${ }^{7}$ Overall, graduates from sandwich courses had higher post-graduation employment rates (69.1\%) than students on equivalent nonsandwich courses (55.3\%). This advantage is dependent on subject area: science and language sandwich graduates for instance did not enjoy a significant advantage but most built environment, business, engineering and social science sandwich graduates did. Of the 33

6 Sources include: Harvey et al., 1997; Rover Group, 1998; Purcell et al., 1999; Sewell, 2001; Lambert et al., 2001.

7 The results of the study are based on aggregated figures. The first-destination returns (FDRs) are collected only six months after graduation and employment rates may not reflect the longer-term pattern in a subject area. The reliability of FDRs is dependent on accurate returns from institutions.

Furthermore, it is not possible to identify whether graduates were employed in their career of choice or in relatively unskilled positions. Subjects taught only on a full-time basis or on a thin-sandwich basis (such as nursing) or with small numbers of sandwich students, were removed from the sample. After excluding residual categories and combined and general studies, an operational sample of 33 subject areas remained for this analysis involving 74,922 graduates. 
subject areas that could be directly compared, sandwich students had the highest employment rate in 21 subjects.

A study of nearly 2000 art and design graduates from 14 British institutions in the mid-1990s (Blackwell and Harvey, 1999) revealed that respondents who had undertaken a workexperience placement had higher rates of full-time permanent employment after graduation. They also had a more favourable view of the undergraduate programme and a belief that their employability skills had been more strongly developed in the undergraduate years. Those who had work experience that was related to their current job also tended to have higher incomes.

These outcomes are mirrored in the Working Out? study: 'Nearly 48 per cent of graduates felt that relevant work experience in a similar organisation was an important factor in enabling them to obtain their job' (Purcell et al., 1999, p. 16). The University Wales Institute Cardiff (UWIC 2003) provides an overview of some research on benefits of work experience and Tony Mooney, in a Guardian article, explored to what extent work experience helped graduates secure a job (Mooney, 2002).

Although good work experience is intrinsically valuable, one reason why it is so strongly associated with success in getting a job is that some employers use work experience as a part of their recruitment process, preferring to recruit from students doing work experience with them. The employers gain by knowing how well these new hires are likely to manage in their firm, instead of having to rely on uncertain warrants to achievement from a university or college. One company, reported in Bennett et al., (2000, p.137) recruited $80 \%$ of its graduates that way.

\section{Recruiting new graduates}

\section{Types of graduate recruitment}

Large graduate recruiters still have some 'fast-track' or graduate training schemes that are designed to produce future managers in the organisation. Even when organisations do not specifically have a policy of fast-tracking, graduates are often expected to progress through the organisation faster than non-graduates. Most 'fast-track' recruiters consider that they are competing for the 'very best' graduates each year.

Yet graduate schemes seem to be less popular than they were and much graduate recruitment is 'direct entry' to do a particular job. This is usually the case in SMEs. With the shift away from graduate schemes in larger organisations has come a degree of decentralisation in graduate recruitment.

Organisations also use job-specific advertisements, usually wanting someone with some relevant experience, and which may also attract postgraduate or non-graduate applicants. This practice may well mean that the number of graduates employed in an organisation is hidden because the person is employed for their experience not as a result of their degree status.

A growing form of recruitment is via work-placement experience (as noted above). Some organisations directly link recruitment to a placement period. Others may recruit a placement student if they have a vacancy. Other forms of work experience, such as holiday working and short-term course-based project working may provide recruitment opportunities. 


\section{Recruitment practices}

Larger organisations often have a set of general criteria or a framework that they use in the selection of candidates through application forms, interviews and assessment centres. Selection criteria may be based on the experience of the individual recruiter or interviewer, may be decided by senior managers or may be the result of internal research into the qualities of successful graduate recruits. Sometimes the criteria are left to external consultants. Criteria for selection are often closely linked to the person specification that has been drawn-up for a particular job.

Employers used to ask potential employers what they had done and, implicitly, what skills they had acquired. Now, they ask what potential students have learned from their experiences and, implicitly, how well equipped they are to learn and continue learning.

In many organisations, recruitment procedures are often designed to recruit people who will 'fit in' to an organisation and get on with things as quickly as possible, despite $80 \%$ of recruiters saying they recruit graduates for their future potential (Park and the Guardian, 2002). It is easier to identify a set of competencies and minimum paper qualifications that provide an indication of value-added potential than it is to design recruitment criteria that encapsulate transformative potential. It is relatively easy to treat a number of competences as discrete items and to specify indicators that demonstrate their presence. Prioritisation, for example, is often gauged via an in-tray exercise. Even so, it is much more difficult to identify some attributes than others: risk-taking, for example is difficult to specify. The application of transformative attributes - synthesis, critique, analysis, decision-making, risk-taking, multilayered communication and innovatory team-work facilitation - is much harder to identify in a decontextualised way than the evaluation of levels of narrowly defined competencies. The real problem is to approach the potential recruit holistically and to assess whether the person will be able to add-value when required but also offer transformative potential. In many cases, this is a step too far for most recruitment processes, especially where the recruiter, as in large organisations, will not be working closely with the recruit.

Recruitment policies and practices that result in 'safe' procedures, which achieve value added as rapidly as possible often sacrifice transformative potential. Practices such as selection based on A-level grades or only looking at graduates from the 'top' universities, perpetuate the league-table mentality irrespective of its validity in identifying potential change agents. The tendency is to disaggregate the person rather than adopt a holistic approach. Likewise, emphasis on sets of competencies can be counterproductive when they are disengaged from the whole person, especially if no account is taken of the role the person is going to play, the context in which that role will be played out and the way it is likely to develop over time. In large organisations, because of the number of applications, recruitment can become a fossilised, bureaucratic process.

There was one happy year when we estimated that between a quarter and a third of all graduates applied to us because we were one of the few organisations that were taking them on, and we had to bring in very stringent paper restrictions, because we were just swamped, we did not know what to do with all these forms, just thousands and thousands of them. (manager, large management consultants)

Safe adaptive-oriented recruitment tends to suggest a financial-oriented, conservative, organisation structure and culture that, out of policy or necessity, sees little need to engage other stakeholders. Thus, the degree of inclusiveness of the organisation is directly related to the level of risk in the recruitment process. 


\section{Biases in recruitment}

All of this leads to an emphasis on same-type recruitment, with consequent, if unintended bias in recruitment. Recruitment practices vary in their sophistication but are not always as transparent as they appear. In 1997, the Graduates' Work report noted:

Far too much recruitment procedure is guided by prejudice, preconceptions and bureaucratic pragmatism, directed towards reproduction of the prevailing culture. It is predominantly 'safe' and oriented towards adding value rather than 'risky' aiming at recruitment of transformative employees. This is a particular problem for large employers but also evident amongst small employers. The response to the increasing numbers of graduates is not to consider the wider range of potential transformative agents, but to narrow down the choice on the basis of spurious criteria such as Alevel grades, degree-classification, or reputation of higher education institution. Placements provide a useful and more appropriate recruitment process for organisations who provide work-based experiences for undergraduates. (Harvey, et al., 1997, p. iv)

Not much, it seems, has changed in the intervening five years.

Age

Some graduate recruiters have, until very recently, openly discriminated on the grounds of age. Upper age limits of 25 are not uncommon on 'fast-track' recruitment. Although some organisations emphasise the benefits of employing mature graduates there is still the slight reservation that mature graduates need to have a number of years left before retirement to make it viable for the organisation to invest in them. AGCAS ran a conference training event in March 2003 on older graduates in the workplace.

Data from the General Household Survey on occupational attainment, showed that, compared to traditional-age graduates, mature graduates were disadvantaged on entry to the labour market (Egerton, 2001). About 15 years on, they have similar attainment to non-mature graduates but as mature graduates are more likely to work in the public or welfare sectors they have lower levels of pay.

\section{Socio-economic status and ethnicity}

Access to What? (Blasko et al., 2002), found that, even after taking the 'indirect effects' (of status of university, subject studied, geographic region) into account, the age and socioeconomic/ethnic background of a graduate appear to influence recruitment decisions.

A study commissioned by the Council for Industry and Higher Education also showed that graduates from lower social groups earn less than those from professional families. 'Graduates from Oxbridge whose father is an associate professional have the highest gain from their degree; their earnings increase by $16 \%$ compared to those graduating from Oxbridge whose father was in a non-middle class occupation' (CIHE, 2002, p. 25).

\section{Gender}

There is little obvious or admitted gender bias in recruitment and often there is encouragement for women to go into traditionally male domains such as engineering, information technology and parts of the financial sector. However, recent research by CEL (2002) showed that six months after graduation male information technology, electronics and 
communications (ITEC) graduates earned 3\% more than females and this grew to $20 \%$ three years after graduation. An earlier study of art and design students also showed salary bias in favour of males (Harvey and Blackwell, 1999).

\section{Qualification}

Qualification may seem like a logical, rather than biasing criterion. However, qualification, especially when it includes A-level grades as well as actual, or potential, degree classification, is closely aligned to socio-cultural factors. Some graduate recruiters, especially 'fast-tack' recruiters, are looking for graduates with 'good' A-levels and a first or upper-second class degree (or, rather more ambiguously, the ability to have achieved one, even if they did not). With the high number of graduates now on the market, employers can specify high degree classifications and still be assured of a large pool of candidates. Whether this will change with the advent of progress files is a moot point.

\section{Institution}

Some employers recruiting graduates onto graduate training schemes tend to target what they call the 'top' universities (although they by no means all have the same list), or target institutions which they feel have been successful in particular areas:

We go for the universities which have the strongest legal departments and these are continually changing. We've just discovered that [University X] has some very good graduates coming out of there at the moment, law graduates, and so we are very alert to changes in the market...We often pay attention to The Times summary of who's got the best law faculties and we are quite pleased when it complements what we think. We have about 12 target universities, the majority of which are old universities, but then last year we recruited 54 trainees from 22 different establishments. (graduate recruiter and training manager, large law firm)

Employers recruit from a limited range of institutions on the assumption that this will filter the kind of recruits they want, ignoring the fact that intellectually and in terms of all the other desirable attributes, there will be as much diversity within universities as between them (Ratcliff and associates, 1995).

\section{Fair recruitment}

These biases have prompted CIHE to issue guidelines for good practice in recruitment (CIHE/ESRU, 2002). There is also a fair recruitment initiative developed by Hobsons and other partners and the Equal Opportunities Commission (2003) provide guidelines for fair recruitment and equalitydirect (2003) provide information on fair recruitment advertising.

Recruitment processes, particularly of large organisations, continue to be skewed in favour of some groups of graduates, often those with A-level entry grades and from institutions who are not always at the leading edge of employability development.

However, recruitment practices are changing, as noted above. There is less recruitment to graduate schemes and more direct job-related recruitment. There is also a growing tendency to recruit from students who have had some work experience with the organisation. Use of the internet for recruitment widens the potential pool of recruits. 
Most employers want, in principle, to develop closer links with higher education. There are practical constraints that restrict the amount of effort that can be put into developing such links. Most employers see recruitment, training and possibly work-experience placements as the basis for links. Few consider it their role to directly or indirectly affect curriculum content and delivery, although some think it would be mutually beneficial if employers became more involved in programmes of study, offering guest lecturers, hosting open days, and so on. There is a good case for using employers' experience of skills training and competence assessment in course development, although employers have limited time and commercial priorities.

Higher education needs to work with employers to identify what is necessary in a graduate education to develop added value but also to ensure that the essential transformative element of a degree programme is retained and enhanced. The agenda is to empower students as critical reflective citizens while also making them aware of the organisational imperatives and modes of working that will allow them to add-value.

There are papers in the Employability Issues for ... series, published in the summer of 2003, addressing employer-HE relations, and the empowerment of students. 


\section{Developments in higher education}

Having established some features of recruitment processes, this reviews initiatives in higher education that are intended to prepare students better for job seeking. As Enhancing Employability, Recognising Diversity (Harvey et al., 2002) showed, there is already a lot of activity in the sector designed to help students make good transitions from higher education to the workplace.

In 1997, the Graduates' Work survey noted that higher education institutions need to be aware of the changing nature of the workplace, the requirements of employing organisations and to be responsive to these changes and demands. Higher education has a responsibility to equip its students:

with more than a profound knowledge of an academic subject area. Higher education has a responsibility to students that includes encouraging and enabling them to develop, through their academic study, a range of explicit attributes, which allow them to subsequently engage effectively in the world of work. (Harvey et al., 1997, p. iii)

In the last five years, higher education institutions have, to varying degrees and at varying rates, addressed the employability agenda in order to help students make easier transitions into the workplace. Initially, skill development dominated the approaches. However, as analyses of employer needs and graduate attributes have become more sophisticated, there has been a shift away from 'skills'. There has been a shift in higher education from seeking to develop specific skills through specialist modules or extracurricular activity to a more holistic approach. Institutions are seeking to develop employability attributes as an explicit and embedded part of academic learning.

\section{Areas of activity in higher education institutions}

There are four broad areas of activity that higher education institutions are engaged in to help develop student employability ${ }^{8}$.

1. Enhanced or revised central support (usually via the agency of careers services) for undergraduates and graduates in their search for work, to this can be added the provision of sector-wide resources.

2. Embedded attribute development in the programme of study often as the result of modifications to curricula to make attribute development, job seeking skills and commercial awareness explicit or to accommodate employer inputs.

3. Innovative provision of work experience opportunities within, or external to, programmes of study.

4. Enabled reflection on and recording of experience, attribute development and achievement alongside academic abilities, through the development of progress files and career management programmes.

8 This categorisation draws on a recent review undertaken for Universities UK (Harvey, et al., 2002). 
These four broad areas of development activity have, in the past, tended to operate in relative isolation from each other. In some areas, especially on 'thin sandwich' courses with embedded and frequent periods of work placement or clinical practice, the integration between work experience, embedded employability development and reflection on achievement is more marked.

However, there is now a trend towards a more holistic approach to employability development across institutions.

The cultural change in higher education has seen a shift towards central support services working with programme staff to help develop attributes as part of the curriculum and maximise reflection on an array of different work experiences. Selfpromotion and career management is no longer a separate activity but increasingly integrated into the programme and linked to career planning and recording achievement. This is important as graduates must be able to do more than just sell themselves; they have to be able to perform in a job once they are recruited. Conversely, potentially good performers also need the skills to get a job in the first place. Emphasis is also being placed on learning to learn, through programmes, with a shift in pedagogy from 'knowing what' to 'knowing how to find out', and through reflecting on work experience. (Harvey et al., 2002, p. x)

Nonetheless, there is a long way to go in many institutions towards developing a fully integrated, high-level, strategic approach to employability. The experience in Wales is salutary. Many institutions had a range of initiatives but rarely a coherent strategy prior to an audit undertaken by the Higher Education Funding Council for Wales (HEFCW) in conjunction with the Welsh Development Agency. Subsequent analysis and follow-up requests from HEFCW asking institutions to produce Work Experience and Employability Plans (WEEPs) encouraged strategic thinking on employability and the designation of a senior manager with responsibility for co-ordination.

The following sections illustrate activities in higher education with examples from Enhancing Employability, Recognising Diversity as well as additional recent material. As far as possible, links to available material on the World-wide Web are included.

\section{Systemic approaches}

The University of Exeter is an example of an institution that has developed a strategy for embedding employability skills and attributes into curricula. The university's employability group is composed of staff from across the institution with an interest in employability and is chaired by the deputy vice-chancellor for learning and teaching. The employability group works to implement the employability strategy, which is managed by the employability coordinator (Lees, 2002a). The university is committed to embedding employability skills and attributes within all programmes of study. To achieve this, academic schools are encouraged to incorporate team development, work experience modules and materials, work-based projects and reflective learning into programmes of study. The employability co-ordinator sits on the accreditation committee with a particular interest in the section on module description forms dealing with intended learning outcomes for 'personal and key skills'. A network of careers and employability tutors has been established with an academic representative appointed from every school. This network meets once a term and is facilitated by the employability co-ordinator. One of the duties of these tutors is to complete the annual careers and employability audit for their school, which is reported to the employability group and the university learning and teaching committee. This helps the employability group to identify which schools may need more support in certain areas. 
Similarly, the University of Newcastle sees enhancing employability as a long-term strategic challenge (Allison et al., 2002). The institution is moving to a strategy-led, rather than projectled, approach by fully integrating project activity to ensure 'fit' with institutional, regional and national priorities. The development of the University of Newcastle's Employability Statement and Strategy reflects the university's commitment, as stated in the 1999-2004 institutional plan. It places high importance, in the teaching and learning strategy on improving the employability of the students. Appropriate resources, often through pump-priming, and practical suggestions help academic staff implement the strategy. Furthermore, senior management support has created a culture that promotes and recognises innovative practice. At the school level, 'champions' with empathy for the employability agenda have helped to build an environment receptive to curriculum change. Crucial, has been the embedding of project-led developments in the curriculum from the outset to overcome problems of sustainability.

However, developments are not uniform across the sector and one well-placed commentator, in a Russell Group university, recently noted:

I think you will find fairly universally that in terms of embedding employability and work-based learning in the curriculum, the red brick universities have some serious catching up to do with their new university/ex-poly counterparts. (curriculum developer in a redbrick university)

For example, despite the Dearing recommendation (NCIHE, 1997) that all students should be familiar with work and that the government should seek ways of getting employers to give more work experience, the University of Birmingham did not take a strategic view of workbased learning until 2002, when the Academic Board endorsed the setting up of a WorkBased Learning Group. The Board had approved a WBL Guidance document in 2000, as a complementary paper to its policy on $\mathrm{AP}(\mathrm{E}) \mathrm{L}$ but little had been done to formalise it. The endorsement of a strategic view was prompted by the development of the Foundation Degree, by approaches from employers to have the university give credit for their in-house training programmes and a change in the structure of National Training Organisations (NTOs) and a move towards the formalisation of National Occupational Standards (NOS). ${ }^{9}$ The university has subsequently inaugurated a strategic process.

\section{Employability audits}

The full extent of embedding of employability within curricula is difficult to assess as development activity is often informal and may include lecturers' business and industry contacts, personal support and encouragement to students and provision of information.

One way to identify what activity is taking place in universities is to undertake employability audits. Following the national audit in Wales, most Welsh institutions have followed up with their own audits of the employability content of programmes and modules. Swansea Institute of Higher Education, for example, undertook an audit of all programmes to determine how key employability skills are embedded. Cardiff University has a periodic review procedure that requires departments to identify skills inherent within schemes and the stages at which these are developed. Heads of schools at Trinity College Camarthen are responsible for specifying which transferable skills are being developed within the module and how they are being developed through the teaching and learning process. University of Wales College, Newport audits programmes to analyse the skills gained by students and to develop an understanding of how innovative teaching encourages and develops employability skills.

9 In addition, the University is part of a consultation exercise being undertaken by the Police Skills and Standards Organisation (PSSO) with a view to greater collaboration between higher education and police forces on all levels of training and development. 
The Work-Based Learning group at the University of Birmingham (2002), for example, undertook a survey, although not comprehensive, which showed that work experience has been long-established in areas such as clinical practice associated with medicine, teacher training, the Diploma in Industrial Studies in Engineering and CPD. On the other hand, there is a new work placement module in the School of Humanities. In addition to clinical practice, traditional sandwich programmes and CPD, the survey revealed that there are generic modules that foster transferable skills available to undergraduate students, which may be based on student work or voluntary activity. There are also employer-based and employmentbased schemes. These include CPD-type programmes in which students use their current work experience on the programme to enhance their professional practice/individual needs, validated programmes, award of credit to employer-provided schemes and awards made on university-provided schemes negotiated with employers.

\section{Outcome statements and benchmarks}

In some institutions the integration of skills in the curriculum is being aided by the restructuring of programmes to identify outcomes or take account of QAA benchmarks. To some extent, this also involves a pedagogical shift. For example, academic departments at the University of Wales, Swansea are expected to provide clear statements about the employment aims of each programme and explain how these are to be achieved. The BA Leisure and Tourism Management at the College of York St John, for example, focuses on the development of learner autonomy and supporting employability-oriented learning objectives.

Integration of key skills in the curriculum, at the University of Glamorgan, takes into account the QAA subject benchmarks and the national qualifications framework. Reliance on QAA benchmarks, though, is problematic as the employability elements of benchmark statements are highly variable between subjects (Harvey, 2001b). There is also a danger that their use will stifle creativity as teachers comply with the hidden national curriculum (Holloway \& Francis, 2002). On the other hand, in engineering, for example, there is compatibility between benchmarks and the Engineering Professors Council Engineering Graduate Output Standard (QAA/EPC, 2002).

\section{Pedagogic developments and managed learning environments}

The introduction of computerised managed learning environments offers another opportunity to embed employability in the curriculum, which, for example, the University of Glamorgan is developing, supported by appropriate teaching and learning materials and staff development. Appropriate use of managed learning environments can encourage new pedagogical approaches to employability, as for example Sheffield Hallam's introduction of Blackboard (SHU, 2002).

Skills plus (Knight and Yorke, 2002; JMU, 2002) is a collaborative project in the North-West involving Liverpool John Moores, Manchester, Manchester Metropolitan and Lancaster universities. A set of practices was developed collaboratively by colleagues in 16 subject areas to produce 'educationally-sound curricula that will enhance employability'. Skillsplus takes the view that employability involves promoting a complex mix of outcomes. It claims that 'highly employable people need understanding, skills of various kinds, efficacy beliefs, and metacognitive fluency - USEM. This view of employability prioritises pedagogy. It is compatible with many descriptions of good learning in general and is not just to do with learning related to work. The approach draws on over 200 semi-structured interviews with new graduates and those working alongside them and nearly 3000 questionnaire returns from undergraduates. It proposes that education for employability is compatible with academia but rather than overly mechanistic outcomes-oriented curricula: 
Learning outcomes tend to look after themselves when learners engage with worthwhile content through a variety of well-conceived learning, teaching and assessment processes that provide occasions for metacognition and consideration of self-theories. (Knight \& Yorke, 2002, p. 11)

A widely used pedagogic device to develop employability skills is group working. However, this is frequently unsupported and students are often grouped together and told to work as a team. At the London School of Economics, Peter Levin and Ivan Kent, with the agreement of tutors, help student groups to work effectively as teams.

There are various web sites available such as the LTSN Engineering site on employability, which is being constructed in response to developments in employability and lists selected resources that could be useful in developing an employability strategy in teaching or useful directly to students in planning their careers. One of the oldest is the Ability Based Curriculum (ABC) network (Oxford Brookes University, 2002), which was one of 34 discipline networks set up by the Department for Education and Employment in 1996 brought together people interested in developing key skills in higher education.

\section{Embedding across the institution}

Increasingly there is a move to have employability explicitly identified within the mainstream curriculum. The University of Bradford, for example, is embedding employability in the curriculum at the departmental level as a continuation from a successful DfEE-funded key skills project 1998-2000. ${ }^{10}$ The current departmental work is based on a university-wide, supported strategy called Excellence Plus, which has three strands: identifying skills on entry, embedding skills in the curriculum and developing skills for the future.

The London College of Printing, which is part of London Institute, has a whole college framework approach to embedding personal and professional development into the three years of the curriculum. It is tailored to the needs of individual subject areas and attracts study credit. Year 1 focuses on academic development skills, such as diagnostic assessment, study skills, introduction to research, time management, and reflective diaries. Year 2 concentrates on enterprise and employability, with a key focus on career management and producing extended curriculum vitae, work-related communications, intellectual copyright, selfemployment, business planning, finance and law related to employability, planning and mounting exhibitions. This is often augmented by work-based learning as an additional credited unit or by voluntary work. The third year, focuses on research and professional practice, supporting the final dissertation or exhibition, with an overview of market trends, future developments and editing and presenting a focussed portfolio.

Fallows and Steven (2000), provide 17 case studies from the UK, USA and Australia that demonstrate how skills development is integrated into courses and institutions.

\section{Subject-specific embedding}

Although there are institution-wide developments, much embedding is still subject-focussed. A DfEE funded key-skills projects based at the University of Gloucester, for example, produced a series of guides for the development of key-skills in geography (Gravestock and Healey, 2000). These included: Key Skills: Teaching and Learning for Transfer, Assessing and Recording a Skills-based Curriculum and guides on improving various skills, such as

10 Other DfEE funded key-skills projects included those at Salford, Gloucester and the NUS (discussed below) as well as projects at Central Lancashire, de Montfort, Leeds, Nottingham and Queen Mary and Westfield. 
communication, numeracy, teamworking, problem solving (GDN, 2000). Transferable Skills and Work-based Learning in Geography (Chalkley \& Harwood, 2000) is a guide is to aid a critical review of the skills and employer-links elements in courses and modules using case studies. It illustrates some of the diverse ways in which geography is responding to the challenge of skills and employability and addresses issues such as how to assess skills, how to design a skills curriculum and how to minimise the administrative burden in work-based learning.

PUNDIT 11(Clarke et al., 2000) was another subject-focused DfEE-funded key-skills project. It was a collaboration between the physics departments of the universities of Leeds and Leicester, the Electronics and Software Services National Training Organisation and Univentures International Ltd who specialise in graduate entrepreneur training. The project surveyed physics students at ten universities to assess their interest in and awareness of ITrelated careers and academic physicists to explore their attitudes towards skills training (and business skills training in particular). Three one-day business skills workshops were then held and a skills audit was carried out in physics degree schemes at Leeds and Leicester. The business skills workshop format will be incorporated into the new 'computing \& careers skills' module for level-2 students at Leeds and business skills workshop are now an optional activity at Leicester. The transferable skills that departments of physics value most highly are communications and IT with languages. Leadership and teamwork were least valued. The employers, on the other hand, rate leadership and teamwork higher than subject knowledge. There is, thus, a mismatch and the departmental surveys have shown that views have not changed over the past six years.

Some of the Fund for the Development of Teaching and Learning (FDTL) projects, 19962002, focussed on the development of transferable skills and employability. ${ }^{12}$ The Keynote Project (a FDTL 3 project) focused on key skills, graduate employability and life-long learning. Although grounded in the areas of textiles, fashion and printing, the outputs are a resource for all students, staff and employers. Nottingham Trent University led the project in partnership with the London Institute and the University of Leeds School of Textiles and Design. It successfully fulfilled its aim to 'disseminate and embed good practice within curricula to enhance students' awareness for future employment and lifelong learning through a realisation of key skills: communication, information technology, numeracy, learning to learn and working with others'. A good practice guide, a resource pack on key skills and a personal development planning guide are all available on the website. 13

The DfEE, Quality and Employability Division established discipline network projects that ran between 1996-8 covering 19 disciplines. Between 1998 and 2000 the Division sponsored four 'innovation and creativity in the curriculum' projects, to identify ways in which the curriculum could be adapted to develop competencies that enable creativity. Subjects involved were architecture and artistic design, fashion and system design, engineering and town planning and urban design.

The University of Nottingham, Institute of Enterprise and Innovation offers 'business planning for science and technology students'. It aims to provide undergraduates with an awareness and understanding of the issues involved in taking a new concept in science and technology to the market place, respond to the aims of UK Government in promoting creativity and innovation in the exploitation of science and technology and enhance entrepreneurial skills. The module involves students working alone and in groups to produce an analysis of a UK company and develop an imaginary idea or a genuine live concept and prepare a business plan for its commercialisation.

11 PUNDIT derives from Physics, Univentures, ESS NTO - Developing Industrial awareness Training for undergraduates)

12 Other FDTL projects included art design and communication at Sunderland,

built environment at Kingston, Luton, and Sheffield Hallam. chemical engineering at Nottingham, chemistry at UEA, engineering at Nottingham and modern languages at Central Lancashire.

13 The website will remain live and updated until August 2004 
A recent study of media courses at four universities showed that current students, recent graduates and employers considered attribute development to be well embedded in programmes (Lambert et al., 2002).

Much of the early work on employability and the curriculum involved the development of stand-alone skills modules rather than the explicit development of employability within the mainstream curriculum. This still continues, the University of Nottingham, for example, has transferable skills modules for first-year history students (Booth, 2001) and the University of Westminster Business School has a compulsory level-1 module on interpersonal skills for business.

Standalone modules or events are more imaginative than they used to be, Westminster has, for example, Westminster Business Consultants, which is a junior enterprise organisation that provides a commercial service and is run, managed and staffed by students. The Business School at The University of Newcastle has developed a Business Enterprise module as a way of embedding an array of attributes in the curriculum.

Some programmes, particularly in the arts, are aware of the self-employment option. At Liverpool John Moores University, there is an optional one-day course for arts students on self-employment that has been in operation since 1997 and had 89 participants last year. It is now attracting attention from graduates in other disciplines.

\section{Central support}

Central support for employability includes any central resource that students or staff can call upon to assist in the development of employability. Usually, this involves a central role for careers services.

\section{Careers Services}

Careers Services in the $21^{\text {st }}$ century are more diverse than they used to be. The image of the Careers Service primarily offering one-to-one career advice sessions for students approaching graduation is outmoded. Careers Services, even if they wanted to, have far too many potential clients to be able to rely on one-to-one advice sessions. Furthermore, careers services are increasingly being drawn into the mainstream of the student experience. They typically collate economic and job-market information, make it available in a variety of ways, aid students in preparing for job interviews, run workshops on a range of areas, take responsibility for job-shops for part-time term-time and holiday work opportunities, run 'onestop-shops' for external enquiries, participate in regional regeneration or development agencies, work in a variety of ways with employers, liase with staff, including helping prepare and run career-development modules or embedding employability in the curriculum and support work experience.

This change will continue in the wake of the Harris Report (DfEE, 2001), which reviewed higher education careers services and made a series of recommendations designed to raise standards and improve performance and to integrate careers services into the organisation as a whole.

A Joint Implementation Group has taken forward the six Harris recommendations that were addressed to the sector as a whole and has published guidance on core services for students, graduates and employers in a report entitled Student Services: Effective approaches to retaining students in higher education (Universities UK/SCOP, 2002). Current work commissioned by the higher education Carers Service Unit (CSU) is exploring the ways 
that careers services ensure that those students most in need of advice are encouraged to seek it.

The need for more and better-integrated career advice and guidance activities is a key message emerging from the study, The Art of Getting Started: Graduate skills in a fragmented labour market (La Valle, O’Regan \& Jackson, 2000).

If nothing else, careers services, working with departments, can do a great service by helping students to realise that they will need to be alert to the growing and varied range of graduate opportunities.

\section{Support for disadvantaged groups}

There is a growing expectation that central services should provide support for disadvantaged groups. An important initiative in supporting disadvantaged students is the AGCAS MERITS Project, which works with Black and Asian students and graduates, who tend to be disadvantaged in the job market. The programme involves careers services at several institutions: Southampton Institute, Manchester Metropolitan, University of Manchester and UMIST, University of Central England, Loughborough, and Brunel universities. The latter has extended this and has piloted a proactive mentoring approach and offers a free Career Planning Resources - hard copy, ring-bound versions of a 'Tutor Pack' and a 'Mentoring Pack'. A final report, Minority Ethnic Recruitment, Information, Training and Support (MERITS) Project (Booth, 2002), was submitted to the Innovations Team and HEFCE.

A group of universities in Yorkshire, Bradford, Huddersfield, Leeds and Leeds Metropolitan, have developed a similar initiative, called IMPACT, that provides tailored support for students to develop their employability skills through confidence building, mentoring and workshops.

Deaf and creative is a web site aimed at young deaf people looking for the next stage in their education or career. There is information about going to university, getting a job, starting a business, doing further qualifications, getting funding and it has job vacancies.

\section{Centrally-provided workshops and events}

Many central support services offer short courses or events on 'job-getting' skills. At the University of East Anglia, for example, students have the opportunity to enrol in a range of extra-curricular, centrally-run, employability-oriented workshops including 'Employability: a round peg in a round hole?', 'Starting your own business', 'Leadership' and 'Entrepreneurial skills'.

Sometimes these workshops are integrated into the curriculum. The University of Bournemouth is currently discussing the issue of adding curriculum vitae workshops and interview-technique workshops, to be run by the Careers Department, to the curriculum for first-year students. This is so that students can be more adequately prepared to engage in employer recruitment processes as they join the second year. Lancaster University's Department of Educational Research worked with careers staff to design careers guidance and curriculum vitae writing programme, which was incorporated into the curriculum in years 1, 2 and 3.

An unpublished survey of Higher Education Careers Service Strategies for Employability by David Pierce_provides an overview of the activities in many institutions as does the AGCAS Directory on Careers \& Personal Development in the Curriculum $4^{\text {th }}$ edition 2001, available on the LTSN Generic Centre website. 


\section{Central support for embedding}

Central support for staff attempting to integrate employability into the curriculum takes many forms, ranging from generic resources produced centrally that can be used by lecturers through to specific help to individual lecturers wanting to enhance a module.

On-line resources produced centrally

Leeds Metropolitan University's Skills for Learning, for example, is an on-line, passwordprotected resource available on and off the campus, accompanied by self-study packs. It claims to be innovative in combining employability development with study skills, information and research, using IT, learning and teaching, group skills, assessment and personal development planning.

\section{Self-help guides}

University of Central England in Birmingham's Careers Service (2002) has produced a selfhelp guide Delivering Employability: A Framework for Career Development in the Curriculum, which identifies attributes that could be developed within curricula. This unique resource suggests how attribute development might be integrated into the programme of study. The suggestions are linked to possible assessments of the development of the attribute. For each attribute, there is a list of other resources that might be useful for lecturers. The resource contains a checklist for employability, which can also be used to audit existing programmes.

\section{Collaborative development}

In several institutions, including Queen's University of Belfast and University of Wales College, Newport, central careers services, lifelong learning departments and academic staff collaborate to develop employability skills in programmes and, where appropriate, share delivery.

The Salford Key Skills Project, initially DfEE-funded until May 2000, (Oakey, Doyle and Smith, 2000 ) is continuing through the HEFCE Teaching Quality Enhancement Fund for a further four-year period. The project team, based in the staff and curriculum development section, are working with staff from across the University to give all undergraduates, as part of their degree programme, the opportunity to develop and record the key skills of communication, numeracy, information technology, team work, problem solving and managing own learning.

The University of Wales, Swansea has appointed an employability and skills officer to work with departments. The officer aids a review programmes of study to identify and enhance vocational elements, embed key skills in programme specifications and promote their value to students. Support and guidance in redesign is provided through the careers centre and the staff development unit.

\section{National skills development programmes}

The National Union of Students (NUS) has also developed the effective and well-established National Skills Learning Programme (NUS, 2002), which began in 1998. In all, 84 student unions have been involved in the scheme, and 52000 students have been trained by peers in at least one key skill. The trainers are all given a portfolio to fill in assist in their reflective learning. 
The Careers Research and Advisory Centre (CRAC) runs GRADschools. This is a nationwide programme of five-day residential courses on which postgraduate students and employees new to the world of work develop their transferable skills as part of their continuing professional development. CRAC will host a national Centre of Excellence at Cambridge supported by a network of regional hubs and other partners. The UK GRAD Programme is primarily funded by the UK Research Councils and the Arts and Humanities Research Board. The Engineering and Physical Sciences Research Council (EPSRC) manages it on behalf of these stakeholders.

\section{Projects helping graduates in(to) work}

Another key area of central involvement is helping graduates into the workplace or to be prepared for the workplace.

\section{Collaborative projects with a focus on SMEs}

Graduates for Growth aims to help SMEs in the Lothians recruit graduates by breaking down the barriers.

A similarly named project was devised and developed by the Foundation for SME Development at the University of Durham, which involves institutions in the North-East and aims to develop graduates talent and widen their career opportunities, whilst offering local SMEs 'lasting benefits through the employment of graduates'.

KITTS (2002), a development in the greater West Midlands area supported by nine higher education institutions helps about 60 SMEs a year to take on graduates to undertake a specific project for up to 13 weeks.

From 1998-2000 the DfEE, Quality and Employability Division established seven 'high-level lifelong learning' projects to aid the continuing professional development of graduates working in SMEs.

\section{Institutional initiatives}

The graduate placement scheme at Canterbury Christ Church University College (CCCUC) is an effective way of using the skills of recent graduates to the mutual benefit of themselves, the local business community and CCCUC. The scheme targets recent or past graduates. It gives them the opportunity to gain paid work experience that will enhance future employment prospects while providing employers with the opportunity to utilise a highly skilled graduate on a work project without the costs of advertising and recruitment. The college careers service matches the graduate's skills to the employer's project requirements and the employer will make the final selection. The college provides ongoing liaison and support with both the employer and the graduate. Similar schemes are successfully running at other universities such as Exeter.

\section{Career Management}

A significant change has been the development of students' own 'career management skills'. Career Management Skills are identified as, 'Enabling individuals to effectively recognise and develop the skills to maximise employability' (University of Derby, 1999). The CRAC Career Management Skills Programme was a pioneer in encouraging students to begin to plan and 
manage their future careers early on while at university. Recently, CRAC has developed InsightPlus as a national scheme that seeks to increase student employability by aiding students' recognition of the skills they develop while undertaking part-time employment or voluntary work. Participants are allocated mentors mainly from large recruiters. There are also careers management skills modules designed to help students and graduates develop and gather evidence of skills, identify career preferences and plan effective job applications.

\section{University initiatives}

The University of Bradford uses the Insight Plus programme to provide additional central support in assisting students in their career management through the Insight Plus programme. This helps students to realistically identify their skills and future career plans. The final report on the pilot year at Bradford is available. The university also offers a module in career and personal development, either as a stand-alone module, or embedded within a department's curriculum. Future work is intended to allow students to reflect more on the skills they develop through work experience.

The University of Reading (2002) is introducing a career management skills component into all undergraduate programmes for new degrees starting in 2002.

The University of Newcastle (2001) makes its career management course available on line and the University of Wales, Bangor's 'career management and job-hunting skills' course is also accredited, at level one, through the Department of Lifelong Learning.

University of Manchester careers service, runs a career management skills programme for second year industrial experience students. It introduces students to key career management skills, helps them search for placement opportunities and give students the skills and knowledge to succeed in the recruitment process.

The Career Management Network is a DfEE Discipline Network project that involves the University of Derby, University of Central England, Nottingham Trent University and De Montfort University. It allows the growing number of academics who are not specialist in career management skills to explores strategies for curriculum integration and share good practice through conferences and the website. The website has a searchable database, information on existing practice and links to sites and case studies, as well as conference papers and discussion opportunities. The University of Derby has a Career Management Skills bibliography on its web site.

\section{Progress files}

Part of the developmental framework for higher education is the introduction of progress files. Following recommendations in the Dearing Report (NCIHE, 1997), Universities UK, Universities Scotland, SCoP and the QAA published a revised joint policy statement on progress files for higher education in February 2001. ${ }^{14}$

The proposed progress files are intended to include transcripts of formal learning and achievement, an individual's reflection and recording of their own personal development and

\footnotetext{
14 A Progress Files Implementation Group (PFIG) was established to monitor and support the introduction of progress files. The PFIG works closely with the Centre for Recording Achievement (CRA) and Personal Development Planning in Higher Education (Scotland) (PDPHESN). The Learning and Teaching Support Network (LTSN) Generic Centre also works with CRA and PDPHESN to support institutions, subject centres and practitioners through briefings, resource packs, seminars and surveys of practice in personal development planning. The CRA web site contains higher education case studies, material and links (Harris, 2001).
} 
personal educational and career development planning. Progress files 'support the concept that learning is a lifetime activity' (QAA, 2002).

Personal development planning (PDP) is an important element of the progress file and should be operational across the whole higher education system by 2005-06 (QAA, 2001). PDP is a structured and supported process undertaken by an individual to reflect upon their own learning and to plan their development.

The intention of PDP is to help students:

- become more effective, independent and confident self-directed learners;

- understand how they are learning and relate their learning to a wider context;

- improve their general skills for study and career management;

- articulate personal goals and evaluate progress towards their achievement;

- encourage a positive attitude to learning throughout life (QAA, 2002).

Edwards, (2001) summarises the results of a major research project sponsored by QAA in 2000 that shows how PDP and the associated student support can be implemented in higher education institutions so that it aids students in recruitment processes and later career management. He notes that most employers put strongest emphasis on the process of PDP rather than the documented outcomes.

There is significant development work, via the Centre for Recording Achievement (CRA), in institutions such as Anglia Polytechnic University (APU, 2002) and the universities of Liverpool, Manchester and Nottingham. Both the University of Plymouth and Edge Hill College have been working on developing PDP since 1997. Partial implementations related to work experience are reported by the University of Central England (UCE), where progress files are designed to help students prepare for, reflect on and evaluate their work experience.

The RAPID 2000 project is an example of the implementation of progress files within a specific subject area. A FDTL Project, it aims to promote skill development on undergraduate programmes in civil and building engineering. Based at Loughborough with partners at UCE, the RAPID Progress File enables students to audit and develop skills in line with the professional competence requirements of leading Professional Institutions within the Industry. The site has six different versions of RAPID for different professional areas but is password protected at the level of entering information.

A recent conference (University of Glamorgan 2002) explored current and prospective developments facilitating personal development planning by students within the Welsh higher education sector. A key objective of the conference was to explore opportunities for institutional collaboration and there was general agreement that institutional collaboration would be of value. However, there was some uncertainty on what form this should take and how it could be initiated. A network within Wales to share good practice was considered a sensible development that could be facilitated by an e-mail information exchange, a seminar programme focussing on practical issues and a collective approach to funding. A pan-Wales network, therefore, may need to operate at two levels: the practitioner level and a policy and funding level (the latter to influence senior management and to make any bids for funding). There was, though, scepticism about the idea of a pan-Wales progress file model. It was also felt necessary to explore links with the further education sector and schools as well as with employers to ensure progression from these other sectors is built in to PDP/progress files in higher education.

Implementation issues reflect the concerns expressed in the literature. Suggested approaches included one or a mixture of the following:

- using a personal tutor system; 
- embedding skills development and reflection into the curriculum and assessment complemented by the holistic use of progress files;

- using specific skills development modules.

The conference report also noted that PDP/progress files need appropriate resourcing if they are to be successful. Success is also dependent on staff at all levels, including senior management, being committed to the implementation of progress files. Whether all academic staff are trained and act as progress file tutors is a moot point but all need to be committed to the principle and to encourage students to engage with PDP. However, institutions should be wary of imposing a rigid reporting and recording structure, which might stifle the real benefits of PDP. Student diversity might call for flexibility; what may be suitable to a recent school leaver may not be suitable for a mature student (Ward \& Pierce, 2003) and the requirements of international students may differ to domestic students.

Progress files offer the opportunity to record a range of achievements, reflect on learning from a variety of sources as well as plan and manage career developments. The internet, perhaps through managed learning environments, provides considerable potential to develop progress files.

A recent trawl of PDP development activity by Bruce Woodcock, Careers Advisory Service, University of Kent at Canterbury, resulted in him posting an anonymised summary of the outcomes. Although not comprehensive it provides a subjective snapshot of some of the more common on-line PDP systems at present available. There are also some useful links from the summary.

One link is to the University of East Anglia course on 'Personal and professional development for Scientists'. The course aims develop skills that will enhance science students' employability. Intended outcomes are, inter alia, to improve students' team working abilities, time management and prioritisation, reliability and accountability, oral, written and visual communication and evaluative skills.

All full time undergraduate courses at the University of Portsmouth (2002) are required to integrate career management skills into their curriculum. The university has developed a compulsory 10-credit, level-2 undergraduate unit on Independent Learning Career Management Skills. The unit is presented via a hard copy handbook that is used in conjunction with dedicated web pages. The unit comprises 10 sessions with a mix of independent learning and class-based tutorials, together with online tutorial support. Students develop an assessed portfolio of work based on the career development process outlined in the unit, which demonstrate their understanding of the process of career development. This integrates with the reflective processes of Personal Development Planning.

On a more general level, Drew and Bingham (2001) have produced a self-evaluation, action planning and reflection aid for students wishing to develop and improve their skills, as have Hodgkinson et al. (2001) for the Open University.

\section{Work experience}

Increasingly, work experience is being seen as a major vehicle to help students make connections between their academic study and the world of work and to familiarise themselves with the skills necessary to be effective in the work setting.

The Dearing report placed considerable emphasis on work experience, concluding, amongst other things, that 'students can benefit from experience in many different settings, structured and informal, paid and unpaid' (NCIHE, 1997, para. 9.30). Employers also benefit from work experience by having staff develop as mentors and enablers, as well as building up links with higher education institutions (Blackwell, et al., 2000). The National Council for Work Experience, now run by CSU, was established to promote work experience and has established a dedicated support website (NCWE, 2002b). 
Work experience can take a variety of forms ranging from traditional placements through 'live' project work to part-time employment. Three main categories of work experience can be identified (Harvey et al., 1998; CSU/NCWE, 1999; Little et al., 2001):

- organised work experience as part of a programme of study;

- organised work experience external to a programme of study;

- ad hoc work experience external to a programme of study.

There is some overlap between categories. Voluntary work, for example, can sometimes be accredited by institutions, is sometimes organised external to the programme of study or may be ad hoc work undertaken by students.

Work experience as part of the programme

There are three main variants of work experience as part of a programme of study.

a. A conventional programme with some work experience element attached to it, either as an optional or compulsory component.

b. 'Generic' work experience modules that are available to students on a range of programmes.

c. Work experience through a programme that is wholly, or predominantly, delivered in the workplace setting.

(a) Conventional programme plus work experience

Work experience on conventional courses includes:

- traditional placements on sandwich courses;

- short periods of work experience on non-sandwich programme;

- clinical or practice placements on some professional degrees;

- 'live' project working, collaboration between students and employers;

- work shadowing.

The work done may or may not be directly assessed towards a final award. Sandwich 'placements' are still taken as the paradigm for work experience although probably fewer than $10 \%$ of students are enrolled on them. In 1998-99, 180,000 UK undergraduates (17.5\% of the total full-time undergraduate population) were engaged on full-time sandwich or non-sandwich programmes that included organised work experience, including clinical and other short-term ('thin') placements on medical, health and teacher training programmes. The proportion of students on sandwich courses varies considerably between institutions, for example, from $55 \%$ at Aston and $44 \%$ at Sheffield Hallam to under $1 \%$ at Birmingham, Warwick, Durham and UMIST (Little, et al. 2001).

Available data underestimate the full extent of programme-embedded work experience. In addition to sandwich programmes and full-time programmes that include compulsory blocks of professional practice, a significant minority of full-time students are involved in short 
placements or 'live' projects with employers (Little et al., 2001). ${ }^{15}$ Courses in library studies, media studies, business and social science often include a short work-placement element, such as the voluntary service learning module on the first-year sociology degree at the University of Liverpool. A final-year module in the BSc Applied Consumer Psychology course at the University of North London, for example, uses 'live' projects.

Work experience on full-time programmes is not confined to undergraduate study. Birmingham University, for example, includes placements in the vocationally-oriented MPhil History, Film and Television offered by the Department of American \& Canadian Studies. The London College of Printing's employability framework enables postgraduate students to take elective units at ' $\mathrm{H}$ ' level in enterprise, project management and work-based learning.

Year-long placements carry an extra cost for students. They pay fees in England and have to extend loans to a fourth year. Paid placements, which predominate, may or may not be sufficient to cover the costs of the extra year.

There is a section of the QAA Code of Practice on Placement Learning that provides a set of precepts, with accompanying guidance, on arrangements for placement learning that is a planned and intended part of an academic programme, which typically takes place outside the institution with the support and cooperation of a placement provider. The Code emphasises the need for clearly defined aims and intended learning outcomes that are understood by all parties and for an explicit specification of responsibilities of the higher education institution, placement provider and student.

PlaceNet (Placements in Industry Network) ${ }^{16}$ is an association open to universities and employer organisations who are actively involved in the placement function in departments of universities, colleges of higher and further education and enterprises/companies offering placement which include, or intend to include, validated and monitored periods of supervised work experience in their curricula.

The development of foundation degrees provides another setting for significant work-based or employer-related learning. The London College of Printing, for example, has 13 foundation degrees and these have encouraged an approach to pedagogy that develops reflective practice. Foundation degree programmes, among other things, have credits linked to workbased learning that use portfolio-based assessment, often linked to design projects for specific clients. In the second year, the emphasis is on pursuing and costing commissioned work, invoicing and getting paid, financial control of small business team working, presentation skills, networking skills, and customer-designer responsibilities

\section{(b) Generic modules}

'Generic' work experience modules include:

- year-long placements unconnected to a specific programme;

- credit for part-time, term-time or vacation work;

- credit for voluntary (unpaid) work;

- programmes developed by student unions for elected officers.

\footnotetext{
15 Many courses include academic projects, which help develop research and presentation skills. These should be distinguished from 'live' employer-linked projects, which are less common. They involve students working directly on a project of concern to an employer. These may be undertaken during a period of work experience and subsumed in the work experience learning or can be used as a substitute for a work-experience placement.

16 PlaceNet was formerly known as the British Association For Business Studies Industrial Placement (BABSIP). It is a registered charity number 1063937 and is governed by a Constitution.
} 
Generic modules are often assessed and count towards the final award. They may also attract separate accreditation.

The University of Wales, Aberystwyth has run the generic Year in Employment scheme for over 20 years, an option taken up by $5 \%$ of students.

One of the earlier examples of accredited generic work-based learning modules was that developed at University College Chester. Students have been able to gain academic credit for their learning achievements in and through work placements since 1992. The assessment process involves students making a presentation to College staff and completing a report in which they are required to reflect on their learning achievements in placement.

The general work-based learning module at the University of Luton, originally validated in July 1993 (Weller, 1994), is accredited as a level-2 module. It was revised in June 2000 to incorporate a more structured approach to help students analyse and reflect upon their learning. It now enables students to focus upon a much wider spectrum of work-experience opportunities than conventional placement learning. To date this module has been taken by 450 students from many different degree programmes.

Learning through Earning, a DfEE Work Experience project at the University of East Anglia (1997-2000), aimed to increase the numbers of graduates well prepared for employment. It offers accreditation for student learning derived from a wide range of work experiences, aims to increase the quality, learning potential and number of work experience opportunities and to produce tested models and materials with potential for wide application throughout higher education. The Work-based Learning Unit is now embedded in the Common Course Structure at UEA and the EmployAbility service offers a wide range of temporary and part-time work to UEA students and a reliable service to local employers. Within the wider university context there has been a gradual appreciation of the value of work experience and skills development and more academic staff now promote the Unit as an appropriate free-choice option.

Middlesex University has an extensive work-based learning programme operating at diploma, degree and masters level. Programmes are customised for individuals or employers, who are from the public, private and voluntary sectors. In 2001-2, 750 students were enrolled, of whom $70 \%$ did not attend a university campus.

The University of Wales, Bangor gives modular credit to second-year students who act as peer guides to first-year's.

The University of Westminster Business School has introduced two models to accredit work experience: 'learning from work' accredits learning from part-time (paid) work and 'team working and leadership skills' accredits learning from unpaid work in the community and environment. Both of these reflective-learner modules designed to enhance employability skills, develop personal development plans and improve career management skills.

The University of East London offers an elective work-based learning module in the School of Education and Community Studies for either paid or voluntary work. The module provides the opportunity to 'earn and learn' by getting part-time work accredited or 'learn to earn' by engaging in relevant part-time voluntary work that will 'provide investment towards future employability and earn credit' towards the degree (UEL, 2001, p. 3)

The Community Enterprise module at Napier University was one of the first generic voluntary work modules. It was open to students across the institution, and reflection on the work experience was assessed towards the degree. Now called Volunteering in the Community it has run since 1994 and has been taken by around 180 students in total (Highton, undated).

Leicester University has offered, since 1996, a Certificate in Voluntary Work, which provides students with an opportunity to gain formal University accreditation for their voluntary activities. 
Sheffield Hallam and Anglia Polytechnic University have stand-alone modules where students can opt to reflect on their learning through volunteering.

Coventry University Student Union (CUSU) provides training for its student representatives and has developed a new initiative called Horizon, which is a programme designed to help students identify, acquire and enhance essential skills not extensively covered by their degree course. Students will obtain an in-depth insight into developing these skills and will have the opportunity to gain a Personal Development Certificate if they complete at least three workshops. The Certificate focuses on eight 'transferable skills' that are highly regarded by graduate recruiters and employers: these are team working, leadership, planning, problem solving, communication, negotiation, presentation and time-management. Horizon is open to all Coventry students.

The STADIA website lists a range of different initiatives including Manchester University Students' Union's Certificate of Personal Development.

\section{(c) Work-based programmes}

Work experience is also achieved through programmes wholly, or predominantly, delivered in the workplace setting. This may include professional learning including CPD, graduate apprenticeships, accreditation of prior experiential learning (APEL) or TCS.

For example, in the 1990s, Vauxhall Motors invited Luton Business School to develop a partly-customised business studies degree programme for its managers. It was delivered using the company's training facilities and involved both work-based learning and traditional taught components. The first cohort completed the programme in 1997 (Kinman \& Kinman, 1998). Vauxhall degree programmes are still in operation, though the delivery will be changed to the university (partly because many of the Vauxhall staff have transferred to IBC Ltd).

Graduate apprenticeships, piloted 1998-2000, aim to link 'a work-based apprenticeship approach to higher education' (DfEE, 1999, p.1). They are frameworks that combine an honours degree or higher-level qualification with work-based learning underpinned by NVQs or National Occupational Standards and key skills (DfEE, 1998). Around 50 higher education institutions are currently developing and delivering graduate apprenticeships, including University of Cambridge's Graduate Apprenticeships (DfES, 2002), which provides CPD in the pharmaceuticals industry.

The National Centre for Work-based Learning Partnerships at Middlesex University (2002) offers a full range of qualifications in work-based learning and professional studies from certificate to doctoral level.

\section{Organised work experience external to the programme}

Students also undertake organised work experience external to the programme of study. The a range of such opportunities includes well-known national programmes, such as CRAC's Insight Plus (2002) and STEP (2003), in which the university plays no direct role in supporting learning. The STEP programme supports eight-week student placements in SMEs. STEP is 'designed to help small and medium-sized businesses and community organisations gain access to highly motivated and skilled undergraduates dedicated to tackle a specific project' (STEP, 2002b). 2002 was STEP's $16^{\text {th }}$ year and 1,200 students took part in the programme. It keeps a high profile through such events as its 'UK's Most Enterprising Student' award.

Other organisations that enable work experience also give awards. The International Association for Exchange of Students for Technical Experience (IAESTE), for example, select their 'Trainee of the Year' and there is also an award for participants in the very best TCS programmes. The Engineering Employers' Federation has a 'Year in Industry' award. In each 
case, the work undertaken by the winners of these awards have contributed significantly to the business they were with. To acknowledge the role played by host employers, the National Council for Work Experience (NCWE, 2002) has launched the NCWE Awards to highlight the companies' significant achievements.

Others external initiatives, such as Business Bridge (2002), Sheffield Plus (2002) and the 'Qualify for Employment' initiative, in which London Guildhall University is an active partner (Cityside, 2002), involve limited support for employability learning from the higher education institution. Science students at the University of Wales, Aberystwyth are encouraged to develop their specialist and generalist skills through work experience arranged by IAESTE. ${ }^{17}$ Little, et al. (2001) provides more detail on these various initiatives.

\section{Volunteering}

Another form of external organised work-experience is voluntary work through Community Service Volunteers, Millennium Volunteers or Student Volunteering UK. There are about 25000 student volunteers across the UK working in community-based projects in over 180 further education and higher education volunteering groups.

SVBangor, for example, is a student-led voluntary group based in the University of Wales, Bangor Students' Union that has been volunteering in the community for over 30 years. The Sussex Coastal Highway (University of Sussex, 2002), run by the University of Sussex Students' Union, is a voluntary programme that encourages local young people from nontraditional backgrounds to progress to higher education. The Experience Works project at the University of Glamorgan identifies opportunities for students to undertake voluntary work experience placements that are relevant to their career aspirations

As noted above, some institutions, such as Napier, Leicester, Sheffield Hallam and APU, provide a way to accredit voluntary working. The College of York St John encourage students to join the Millennium Volunteers Programme and use this experience towards their accredited work experience module in Semester 2 of their second year. However, most volunteering is not formally accredited but students use it to develop claims to employability and to explore different potential career paths.

The case studies of 'The Art of Crazy Paving' research project (Speakman, Drake and Hawkins, 2001) showed that volunteering promoted an organic learning process that honed continuing personal development planning and self-reflection.

A new HEFCE stream of funding is the Active Communities Fund (HEACF), encouraging students to volunteer. Every HE institution has substantial funding, which could aid the enhancement of employability.

Recent research amongst 200 of the UK's top businesses shows that three quarters of employers prefer to recruit candidates who have undertaken voluntary work experience and that over half think that voluntary work can be more valuable than paid work (Reed Executive, 2001).

Guide for Busy Academics No.5. Enhancing student learning through voluntary work (LTSN Generic Centre, 2001) briefly outlines the nature and advantages of volunteering and suggests a personal development plan template that could be used by students engaging in voluntary activities

17 Some students get limited work experience through structured courses offered by private organisations. However it is unlikely that this includes many students who are not getting experience through other routes (Little et al, 2001). 
Increasingly, students obtain work experience through casual, part-time or vacation work or, for part-time students, through their own full-time employment or other activities.

Institutionally-based surveys found that the majority of students already had work experience before entering higher education (Work Experience Bank, 1998). The Work Experience Bank is being developed as a new national resource to help students make the most of all forms of work experience from part-time jobs to one-year industrial placements.

Recent surveys show that $50-60 \%$ of full-time students work during term-time and probably $80 \%$ of full-time students work over the summer vacation. The indications are that the proportion of full-time students working is increasing and that they are working on average around $10-14$ hours a week during term-time. ${ }^{18}$

The increase in part-time working is greatest among low income and older students, students living at home with their parents, female students (especially from ethnic minorities), students attending a university in London or Scotland or attending 'post 1992' universities, students with low A-level scores on entry to university and those whose father was not a graduate. Students from low-income families also tend to work longer hours. Similarly, men, students studying in London and in Scotland, and students who have taken out a student loan are most likely to work 20 hours or more a week. 19

Traditionally, part-time working during term-time was seen as 'interfering' with academic work (THES, 1998; Brennan and Shah, 2002). Now, most universities run job clubs for students or support student search for part-time work. For example, Sheffield Hallam University's student employment week aims to help students find suitable and manageable employment alongside their studies if they need to generate additional funds (SHU, 2003). In some places, as noted above, the learning from part-time work is being taken more seriously and given credit.

JEWELS (Joint Systems to Enhance Work Experience Levels of Service and Satisfaction), a DfEE work experience project at the Universities of Exeter and Plymouth, set out to improve the quality of ad hoc work experience by establishing a programme in which undergraduates/graduates might optimise and record their learning from work and have the opportunity to see it recognised within a related accreditation framework. As a result Exeter has a level-2 independent work experience module, run by the school of education and lifelong learning, which any student can opt to take. In addition, three schools have adapted this module and embedded it within their own programmes of study and a further six schools are in the process of embedding all or part of it in their curricula. The University of Plymouth has a level-2, 10 credit, Independent Work Experience 'shell' customised for specific programme areas.

\section{Learning from work experience}

The Work Experience report (Harvey et al., 1998) argued that experience of work should not be regarded as something that is intrinsically beneficial. On the contrary, it is the learning that comes from the experience that is important. This view now appears to predominate within higher education institutions and is reflected, for example, in the approach adopted by the National Council for Work Experience (NCWE, 2002a), InsightPlus and the NUS.

18 Research sources include: Daniel, 2002; Barclays, 2001; Callender and Kemp, 2000; Newell \& Winn, 2000; Unite/Mori, 2000; Smith and Taylor, 1999; NUS, 1999; Walker, 1999; Taylor, 1998; Rover Group, 1998: Lucas and Ralston, 1997; Hallowell, 1995; Paton-Saltzberg \& Lindsay, 1995; Mason and Harvey, 1995; Ford et al., 1995; Edmundson \& Carpenter, 1994.

19 Sources include: Callender, 2001a, 2001b; Connor et al., 2001; Metcalf, 2001; Barke et al., 2000; Callender \& Kemp, 2000. 
Different forms of work experience offer different benefits and students may participate in a range of work experiences. This fits in with viewing learning as a transformative process that is not restricted to particular institutions of learning.

Learning from work experience is effective if:

- it is meaningful;

- there is an intention to derive learning from it;

- it is assessed or accredited;

- the quality is monitored;

- it adds to a work experience portfolio;

- there is a process for articulation and reflection (Harvey et al., 1998).

If work experience is meaningful or relevant to the future career development, then it appears to be more useful and effective as a learning tool, in aiding personal development planning and in enhancing career prospects. If 'non-traditional' forms of work experience are to be maximised for their learning opportunities, then students need some kind of structure and support so they can reflect upon and articulate the learning.

If the learning from work experience is planned and intentional from the outset it is easier for students to reflect on it and identify what has been learned. This can be supported by using learning contracts, which identify specific goals.

There is pressure to assess work experience formally and accredit it so that it is integrated into undergraduate programmes. Assessment also provides evidence of learning, which may be demanded by higher education institutions and employers. Assessment ranges from 'satisfactory completion' of traditional sandwich placements, through credit awarded toward degrees for generic modules, to separate awards of the institution, employer schemes, or of an independent body (such as City and Guilds licentiateship or NVQ). ${ }^{20}$ Evidence suggests that students prefer nationally-recognised accreditation of work experience to local schemes. Unfortunately, there has been little progress, despite several attempts, towards a national scheme. There is little hard evidence that employers are interested in the accreditation of work experience. The emphasis in institutions is now shifting towards documenting work experience through progress files, which are likely to fulfil the certification and accreditation role in a rather more inclusive and consistent manner.

To ensure work experience is a quality experience, employers, participating academics and students must all be committed to it and be fully aware of the implications. Planning and responsibility for success need to be shared, which means ensuring adequate, trained and supportive supervision. The quality of work experience is greatly enhanced by prior induction and briefing, facilitation of ongoing reflection by the student, debriefing and identification of outcomes.

Ideally, students would be encouraged to develop a varied work-experience portfolio, such as a mixture of course-embedded placements and part-time working. Mature students, for example, may have different work-experience requirements from traditional graduates. This

20 The Work Experience (Harvey et al., 1998) report noted that a widening of work experience raises four kinds of issues around assessment:

- assessment to make work experience 'valuable' to students (instrumentalism);

- making work experience equivalent to non-work experience (equal amounts of assessed work);

- assessing the development of a range of attributes not just written output (assessing the experience);

- shifting the emphasis to give the student more opportunity and responsibility to develop as an independent learner. 
can be represented through progress files and incorporate school-based work experiences thus developing a seamless approach.

Providing a framework for students to reflect on and articulate learning from work experience in an ongoing way is pivotal to employability development. When recruiting, employers are interested in the ability to identify and communicate what has been learned from work experience. However, reflection needs to be seen in a wider sense than reflecting on the development of narrowly-defined, job-relevant skills. Although retrospective reflection on work experience can be meaningful, a well-planned experience, with ongoing and built-in, 'realtime', reflection, linked to identifiable outcomes, is likely to optimise the learning potential.

If Only l'd Known (Hawkins \& Gilleard, 2002) is intended to encourage students to make the most of their university experience by getting involved in a range of activities, building up an experience portfolio and reflecting on what they are getting out of their whole student experience. The National Centre for Work Experience has also produced the Work Related Learning Report (NCWE, 2002).

Reflection and articulation can be assisted by Skills Trackers, such as the NUS online skills tracker, which generates a learning log, the AIESEC Tracker (1998), the Prospects Planner on-line, developed by CSU and AGCAS, and Skills On-line (STEP, 2002a), which helps students identify skills development. Skills On-line also generates a STEP-approved placement portfolio to show future employers, allows students to browse graduate job vacancies and employer profiles and allows them to set preferences to receive information on specific employers and jobs. The various on-line skills and personal development programmes for students, such as the UEA Matrix, are not dissimilar to these skills trackers.

In most instances, where students have formal work experience placements there is an established procedure for monitoring and aiding reflection, especially where the placement is accredited or successful completion is necessary for progression. The University of Bournemouth provides an example of the monitoring and reflection process. Students are required to keep a logbook or diary of their placement (weekly entries) detailing activities, targets, skills used, difficulties encountered and how they overcame them, as well as what they learned. This has to be signed by their supervisor on a regular basis. Towards the end of the placement students also complete a specific assignment of 2,500 words that brings together their findings. Placement development advisors visit students in situ on two occasions during the 40-week placement. The advisor speaks both to the student and to the workplace supervisor and produces a report identifying progress made from visit to visit, including learning and skills development. Finally the company is asked to complete a onepage appraisal form (matrix of skills). The pieces of work, the logbook, the PDA reports provide an overall picture of the placement. 


\section{Conclusions}

The requirements of employers are sometimes seen to be at odds with academia. However, a closer analysis of the sorts of things employers are looking for reveals that there are congruities between the abilities developed in higher education and those desired by employers (Harvey \& Knight, 1996). The problem, when it arises, tends to be in the first few months of transition to work. Not only do employers expect more from graduates, they expect them to be effective more quickly. The transition is complex and is enhanced if student's tacit knowledge is honed. This is both a function of the awareness and application of the graduate and the opportunities afforded graduates by higher education.

The last five years have witnessed an accelerating pace of engagement with employability within the academy. Initial, piecemeal accommodation of employability through skills modules has developed into a more diverse array of opportunities. In some institutions, they have been developed into an integrated, holistic strategy, most recently linked to learning and teaching policy.

Indeed, it is this integrated approach and the clear emphasis on learning that have moved employability into centre stage.

Nonetheless, many activities in institutions are pump-primed via various nationally funded initiatives. This is a problem for the development and maintenance of an integrated strategy. Although externally-funded initiatives can be extremely useful in kick-starting activity, they can be of limited impact if they are perceived as transitory or marginal.

Often such initiatives lead to activity for a couple of years and then the process dies due to lack of funding. In some cases initiatives are extended, as has been shown seen, by being embedded in institutional processes and cultures. However, it is often difficult to track down what has become of funded initiatives. To that end, 'Bridging the Gap' was designed as a year-long study to maintain an information flow. It was established in 1998 and was based in the Centre for Higher Education Practice at the Open University, funded by the Department for Education and Employment (DfEE) Innovations Fund. Over 55 projects received funding during the year of 'Bridging the Gap' including projects on key skills, recording achievement, innovation and creativity in the curriculum, graduate business start-ups and work experience.

Dissemination of best practice is the key to maximising the effectiveness of projects funded by bodies such as the DfEE. The launch of the Bridging the Gap project signals a desire on the part of funding bodies to ensure that outcomes from projects are not lost when funding ends and teams disband (Godfrey Pell, Project Manager)

However, while the website provides outlines of the various projects, there appear to be no working links to the final project reports, which is not unusual.

Despite its co-ordinated strategy and imaginative commitment to employability, even the University of Exeter is concerned about long-term funding.

We have a lot of good ideas, good relationships with academic schools, many of which are responding well to ideas about curriculum development taking into account employability. It is however, difficult to plan long-term if funding for projects and personnel is short-term and lacking continuity. (Lees, 2002c) 


\section{References}

All sites were accessed in February 2003, dates of web-based material are the dates shown on the site. Where sites are undated then the date of access is give viz. 2003.

Association of Graduate Careers Advisory Services (AGCAS), 2001, Directory on Careers \& Personal Development in the Curriculum $4^{\text {th }}$ edition. This is on the AGCAS Intranet and on the Generic Centre website http://www.agcas.org.uk/

Association of Graduate Careers Advisory Services (AGCAS) MERITS Project, 2002, http://careers.mmu.ac.uk/mentor/about.htm

Allison, J., Harvey, C. \& Nixon, I., 2002, Enhancing Employability: A long term strategic challenge. University of Newcastle. Available on the LTSN Generic Centre website as EMP002,

http://www.Itsn.ac.uk/application.asp?app=resources.asp\&process=full_record\&section=gene ric\&id=164

Anglia Polytechnic University Student Development, 2002, http://www.apu.ac.uk/studentdevelopment/

Anglia Polytechnic University (APU), 2002, Recording achievement case study http://www.recordingachievement.org/case_studies/cs_detail.asp?sid=39

ASET, 2002, Integrating work and learning in Europe, ASET Annual Conference Proceedings. Fitzwilliam College, Cambridge 3-5 September 2002. Sheffield, ASET ISBN 0954-2231-1-X

Association Internationale des Étudiants en Sciences et Commerciales (AIESEC), 1998, 'The AIESEC Tracker', http://aiesec.org/uk/web/frrbotto.htm

Association of Graduate Recruiters (AGR), 1995, Skills for Graduates in the 21st Century. Cambridge, AGR.

Association of Graduate Recruiters (AGR), 2003, Graduate Recruitment Survey, Warwick, AGR http://www.agr.org.uk/news/news_view.asp?news\%5Fid=247

Atkins, M. J., Beattie, J. and Dockrell, W, B., 1993, Assessment Issues in Higher Education. Sheffield, Employment Department.

Barclays, 2001, Barclays Student Survey 2001, London, Barclays Bank. http://www.newsroom.barclays.com/news/data/733.html

Barke, M., Braidford, P., Houston, M., Hunt, A., Lincoln, I., Morphet, Stone, I., and Walker, A., 2000, Students in the labour Market: nature, extent and implications of term-time employment among University of Northumbria undergraduates Research Report RR 215, Department for Education and Employment, London.

Bennett, N., Dunne, E. \& Carré, C., 2000, Skills Development in Higher Education and Employment. Buckingham, Society for Research into Higher Education and Open University Press. http://www.ics.Itsn.ac.uk/books/reviewed/031.htm

Binks, M., Grant, A. and Exley, K., 1993, 'Assessing the output of institutions of higher education: a pilot study', in Harvey, (Ed.), 1994b, Proceedings of the Second QHE Quality Assessment Seminar, 16-17 December, 1993. Birmingham, QHE, pp. 18-28.

Birmingham University, 2002, MPhil History, Film and Television http://www.universitiesuk.ac.uk/bookshop/downloads/employability.pdf 
Blackwell, A. and Harvey, L., 1999, Destinations and Reflections: Careers of art, craft and design graduates. Birmingham, Centre for Research into Quality.

http://www.uce.ac.uk/crq/publications/dr/index.html

Blackwell, A., Bowes, L., Harvey, L., Hesketh, A.J. and Knight, P.T., 2000, 'Transforming work experience in higher education', British Educational research Journal, 27(3), pp. 269-86.

Blasko Z, with Brennan, J., Little, B. and Shah, T., 2002, Access to what?: Analysis of factors determining graduate employability, London, Centre for Higher Education Research and Information (CHERI). http://www.hefce.ac.uk/Pubs/RDreports/summary/summ16.htm The final report of the project is likely to be published early in 2003.

Booth, A., 2001, 'Developing history students' skills in the transition to university', Teaching in Higher Education, 6(4).

Booth, J., 2002, Minority Ethnic Recruitment, Information, Training and Support (MERITS) Project, no. 49, AGCAS. http://www.agcas.org.uk/merits/pdf/MERITS_Project_Finalre.pdf

Bowes, L. and Harvey, L., 2000, The Impact of Sandwich Education on the Activities of Graduates Six Months Post-Graduation. London, National Centre for Work Experience and the Centre for Research into Quality.

http://www.uwic.ac.uk/uwicnet/studserv/workplacement/research_on_benefits_of_work_exper ience.htm\#Bowes

Brennan, J., Kogan, M. \& Teichler, U. (Eds.), 1996, Higher Education and Work. London, Jessica Kingsley.

Brennan, J. and Shah, T., 2002, Access to What? How to Convert Educational Opportunity into Employment Opportunity for Groups from Disadvantaged Backgrounds. Interim Report on Phase 2. London: The Centre for Higher Education Research and Information.

British Telecom (BT), 1993, Matching Skills: A Question of Demand and Supply. London, BT.

Brown, S. and Knight, P., 1994, Assessing Learners in Higher Education. London, Kogan Page.

Brunel University, 2002, Career Planning Resources

http://www.brunel.ac.uk/careers/proactive_mentoring.shtml

Burrows, A., Harvey, L. and Green, D., 1992, Is Anybody Listening? Employers' Views on Quality in Higher Education. Second edition, December 1992. Birmingham, QHE.

Business Bridge, 2002, http://www.business-bridge.org.uk

Callender, C., 2001a, Supplementary memorandum Appendix 36 Higher Education: Student Retention Sixth Report Education and Employment Committee, HC 124, HMSO, London. http://www. parliament.the-stationeryoffice.co.uk/pa/cm200001/cmselect/cmeduemp/124/124ap44.htm

Callender, C., 2001b. The Impact of Student Debt on Participation and Term-Time Employment on Attainment: What can research tell us? A Summary. October. London, UUK, CHERI and South Bank University

Callender, C. and Kemp M., 2000, Changing Student Finances: Income, Expenditure and Take-up of Student Loans Among Full- and Part-time Higher Education Students in 1998/9. Research Report RR 213, Department for Education and Employment, London.

Cannon, T., 1986, 'View from industry' in Moodie, G. C. (Ed.), Standards and Criteria in Higher Education, Guildford, Society for Research into Higher Education (SRHE) \& NFER/Nelson, pp. 145-56. 
Canterbury Christ Church University College (CCCUC), 2002, Graduate Placement Scheme, http://careers.cant.ac.uk/gps/

Cardiff University 2002, Review Procedure http://www.cf.ac.uk/areg/quality/review/

Careers Research and Advisory Centre (CRAC), 2002, InsightPlus,

http://www.crac.org.uk/insight/insightplus/insightplus.htm or http://www.insightplus.co.uk

Careers Research and Advisory Centre (CRAC), 2003, GRADschools

http://www.crac.org.uk/insight/gradschools/grad(frame).htm

Careers Service Unit and National Centre for Work Experience (CSU/NCWE), 1999, "What is work', pp. 6-7, Focus on Work Experience. Manchester, CSU. 2003 issue of Focus, see http://www.prospects.ac.uk/cms/ShowPage/Home_page/Articles/Focus_on_Work_Experienc e_2003/p!eLaXfX

Caswell, P., 1983, 'Graduate recruits: what do employers look for?', Teaching News, 18, March, pp. 13-15.

Centre for Higher Education Practice, Open University, 1998, Bridging the Gap'

http://www.innovations.ac.uk/btg/projects/index.htm

Centre for Recording Achievement (CRA)

http://www.recordingachievement.org/Current_Projects/

Chalkley, B. \& Harwood, J., 2000, Transferable Skills and Work-based Learning in Geography http://www.chelt.ac.uk/gdn/guides/summary.htm\#Skills

Cityside, 2002, Cityside Regeneration: Brining success to Spitalfields http://www.cityside.org.uk/cityside_regeneration.htm

Clarke, A., et al., 2000, Final report of project PUNDIT, Leeds, University of Leeds http://www.dfes.gov.uk/dfee/heqe/punexec.doc

Collective Enterprise Ltd (CEL), 2002, 'The experience of recent graduates in IT, electronics and communications (ICET). Summary paper, prepared for a presentation at the Conference Centre, Victoria Street, London, 18 April, 2002.

College of York St John, 2002, BA Leisure and Tourism Management http://www.universitiesuk.ac.uk/bookshop/downloads/employability.pdf

Community Service Volunteers, 2003, http://www.csv.org.uk/csv/ie4.htm

Conference Board of Canada (CBC), 1992, Employability Skills Profile: The Critical Skills Required of the Canadian Work Force. Toronto, CBC

Conference Board of Canada (CBC), 2002, Employability Skills 2000+. Toronto, CBC http://www.conferenceboard.ca/education/learning-tools/esp2000.pdf

Connor, H., Dawson, S., Tyers ,C., Eccles, J., Regan, J., and Aston, J., 2001, Social Class and Higher Education: issues affecting decisions on participation by lower social class groups. Research Report RR 267, Department for Education and Employment, London.

Council for Industry and Higher Education (CIHE), 1996 A Learning Nation The Council's policy document and submission to The National Committee of Inquiry into Higher Education. CIHE, November 1996.

Council for Industry and Higher Education (CIHE), 2002, Rates of Return to Qualifications: A Summary of Recent Evidence Dr Gavan Conlon Dr Arnaud Chevalier Centre for the 
Economics of Education London School of Economics http://www.ciheuk.com/publications_returns.htm

Council for Industry and Higher Education (CIHE)/ESRU, 2002, Employers in the New Graduate Labour Market: recruiting from a wider spectrum of graduates: a project commissioned by the Higher Education Funding Council for England as part of the Innovations in Higher Education Programme, conducted by the Employment Studies Research Unit at the University of the West of England in partnership with The Council for Industry and Higher Education, Report by Purcell, K., Morley M. \& Rowley, G., May, http://www.cihe-uk.com/THE\%20FINAL\%20FULL\%20REPORT.pdf

Coventry University Student Union (CUSU) 2002, Horizon, http://www.coventry.ac.uk/su/horizon/index.html

Careers Service Unit (CSU)

http://www.prospects.ac.uk/cms/ShowPage/Home_page/About_us/Who_are_CSU_/p!egijdk

Careers Service Unit (CSU), 2003, What do graduates do? based on 2001 HESA data. http://www.prospects.ac.uk/cms/ShowPage/Home_page/What_do_graduates_do_2003/p!eklFie

Daniel, A., 2002, Working for Yourself? Employability study among fine art and jewellery and silversmithing students 2001-2002. Birmingham, Birmingham Institute of Art and Design, UCE. http://www.biad.uce.ac.uk/research/projects/employResearch/employRes.html

Davies, G., 1993, 'HEFCE quality assessment methodology: how it addresses employereducation links', in Harvey, (Ed.), 1994b, Proceedings of the Second QHE Quality Assessment Seminar, 16-17 December, 1993. Birmingham, QHE, pp. 32-6.

de la Harpe, B., Radloff, A. \& Wyber, J., 2000, Quality and generic (professional) skills. Quality in Higher Education. 6(3) 231-43.

Deaf and creative, 2003, http://www.deafandcreative.ac.uk/

Department for Education and Employment (DfEE), 1998, 'Higher education and employment: "Graduate Apprenticeships"', National Training Organisation Division, unpublished.

Department for Education and Employment (DfEE), 1999, Higher Education: Quality and Employability Digest, December 1999. Sheffield, DfEE.

Department for Education and Employment (DfEE), 2000, Higher Education Digest Special Issue on Higher Education Development Projects. Autumn.

www.dfes.gov.uk/dfee/heqe/cheri_dfee_digest.pdf

Department for Education and Employment (DfEE), 1998, Quality and Employability Division, 1996-8, Discipline Network Projects, http://www.dfes.gov.uk/dfee/heqe/discnetprojs.htm http://www.dfes.gov.uk/dfee/heqe/discnet_99-00.htm

Department for Education and Employment (DfEE), 2001, Developing Modern Higher Education Careers Services. Report of the Review led by Sir Martin Harris, Vice-Chancellor, Manchester University. DfEE/1701/200. Nottingham, DfEE Publications http://www.dfes.gov.uk/hecareersservicereview/

Department for Education and Skills (DfES), 2002, Graduate Apprenticeships http://www.dfes.gov.uk/graduateapprenticeships/index.shtml

Department of Employment (DE), 1981, Higher Education and the Employment of Graduates. Unit for Manpower Studies, Research Paper No. 19. London, DE.

Drew, S. \& Bingham, R., 2001, The Student Skills Guide. Aldershot, Gower. 
Dunne, E., Bennet, N. \& Carré, C., 2000, 'Skill development in higher education and employment', in Coffield, F. (Ed.) Differing Visions of a Learning Society. Research findings, volume I. The Policy Press \& ESRC. http://www.lifelonglearning.co.uk/iln/n1-19.htm

Edge Hill College 2002, Recording achievement case study http://www.recordingachievement.org/case_studies/cs_detail.asp?sid=82 see also http://www.universitiesuk.ac.uk/bookshop/downloads/employability.pdf

Edmundson, T. and Carpenter, C., 1994, University of Westminster Students' Financial Circumstances Report 1994. London, University of Westminster.

Edwards, G., 2001, Connecting PDP to Employer needs and the world of work, Available on the LTSN Generic Centre website as PDP011.

http://www.Itsn.ac.uk/application.asp?app=resources.asp\&process=full_record\&section=gene ric\&id=71 A full report on the project is also available: Edwards, G. Employer Input to Support the Further Development of Progress Files Project Report to QAA (August 2000)

http://www.qaa.ac.uk/

Egerton, M., 2001, 'Mature graduates I: occupational attainment and the effects of labour market duration', Oxford Review of Education, 27(1), pp. 135-50.

http://www.iser.essex.ac.uk/pubs/abstracts/m-egerton.php

Engineering and Physical Sciences Research Council (EPSRC) The UK GRAD Programme http://www.epsrc.ac.uk/website/default.aspx?ZoneID=2\&MenulD=1244

Engineering Employers' Federation (EEF), 2003, 'Year in Industry' http://www.yini.org.uk/

Equal Opportunities Commission (EOC), 2003, 'Is your recruitment fair?'

http://www.eoc.org.uk/cseng/advice/is_your_recruitment_process_fair.asp

Equalitydirect, 2003, Information on recruitment advertising. http://www.equalitydirect.org.uk/

Expert Group on Future Skills Needs (EG), 1998, Responding to Ireland's Growing Skills Needs. The first report of the Expert Group on Future Skills Needs to the Tánaiste, and Minister for Enterprise, Trade and Employment and the Minister for Education and Science. Dublin, Forfás. http://www.forfas.ie/futureskills/reports/fskills.htm other reports can be accessed at http://www.forfas.ie/futureskills/

Fallows, S. \& Steven, C., 2000, Integrating Key Skills in Higher Education: Employability, transferable skills and learning for life. London, Kogan Page.

Fergus, A., 1981, 'Selecting new graduates for administration and management', BACIE Journal, 36, no. 1, pp. 19-21.

Ford, J., Bosworth, D. and Wilson, R., 1995, 'Part-time work and full-time higher education', Studies in Higher Education, 20(2), pp. 187-202.

Fulton, O., Gordon, A. and Williams G., 1982, Higher Education and Manpower Planning. Geneva, ILO.

Future Skills Wales (FSW), 1998, A Report Addressing The Future Skill Needs of Wales, 1998-2007: Main Report for All Wales. A report produced by MORI Research and Business Strategies Ltd. For news of FSW 2003 see

http://www.elwa.ac.uk/services/printer.asp?pageid=2029\&ds=elwaR

Geography Discipline Network, 2002, Summaries of the DfEE-funded 'Key Skills in Geography in Higher Education' Guides, http://www.chelt.ac.uk/gdn/publ.htm\#dfee 
Gordon, A., 1983, 'Attitudes of employers to the recruitment of graduates', Educational Studies, 9, no. 1, pp. 45-64.

Graduates for Growth, 2003, http://www.graduatesforgrowth.org/

Gravestock, P. \& Healey, M., 2000, Key Skills in Geography in Higher Education, Geography and Environmental Management Research Unit, Cheltenham and Gloucester College of Higher Education. http://www.chelt.ac.uk/gdn/confpubl/final.htm

Green, S., 1990, Analysis of Transferable Personal Skills Requested by Employers in Graduate Recruitment Advertisements in June 1989. Sheffield, University of Sheffield.

Hallowell, S., 1995, Student Finance Survey 1994/5. Leicester, Leicester University.

Harris, N., 2001, 'Progress files', Higher Quality, p. November, p. 1.

Harvey, L. and Blackwell, A., 1999, 'Gender bias in incomes of art and design graduates', Industry and Higher Education, 13(5), pp. 323-29.

Harvey, L. and Knight, P.T., 1996, Transforming Higher Education. Buckingham, Society for Research into Higher Education (SRHE) and Open University Press.

Harvey, L. with Green, D., 1994, Employer Satisfaction. Birmingham, QHE.

Harvey, L., 2000, 'An Employability Performance Indicator?', Perspectives, 4(4), pp.105-9.

Harvey, L., 2001a, 'Defining and measuring employability', Quality in Higher Education 7(2).

Harvey, L., 2001b, 'The British experience of assessing competence', in Palumbo, C.A. and Banta. T. (Eds.), Assessing Student Competence in Accredited Disciplines: Pioneering approaches to assessment in higher education. Sterling, Virginia, Stylus.

Harvey, L., 2003, Deconstructing employability', forthcoming

Harvey, L., Burrows, A. and Green, D., 1992, Someone Who Can Make an Impression. Report of the Employers' Survey of Qualities of Higher Education Graduates. Birmingham, QHE.

Harvey, L., Geall, V., and Moon, S. with Aston, J., Bowes, L. and Blackwell, A., 1998, Work Experience: Expanding opportunities for undergraduates. Birmingham, Centre for Research into Quality. http://www.uce.ac.uk/crq/publications/we/

Harvey, L., Locke, W. and Morey, A., 2002, Enhancing Employability, Recognising Diversity: Making links between higher education and the world of work. London, Universities UK and CSU. http://www.universitiesuk.ac.uk/bookshop/downloads/employability.pdf

Harvey, L., Moon, S. and Geall, V with Bower, R., 1997, Graduates' Work: Organisation change and students' attributes. Birmingham, Centre for Research into Quality (CRQ) and Association of Graduate Recruiters (AGR). http://www.uce.ac.uk/crq/publications/gw/

Hawkins, P. \& Gilleard, C., 2002, If Only l'd Known: making the most of higher education, a guide for students and parents. Available on the LTSN Generic Centre website as EMP003 http://www.Itsn.ac.uk/embedded_object.asp?id=17858\&prompt=yes\&filename=EMP003

Higher Education Funding Council for England (HEFCE), 2002, Higher Education Active Communities Fund (HEACF) http://www.hefce.ac.uk/Reachout/heacf/ 
Higher Education Funding Council for Wales (HEFCW) 2000, 'Work Experience and Employability Plans', HEFCW Circular WOO/52HE

http://www.wfc.ac.uk/education/hefcw/pub00/w0052he.html

Higher Education Funding Council for Wales (HEFCW), 1999, Pilot Audit of Employability provision in higher education institutions in Wales. Cardiff, HEFCW.

Highton, M., 2003, Reflection in Work-based Learning for Undergraduates. Edinburgh, Napier University http://www.recordingachievement.org/downloads/100083.pdf

Hodgkinson, L. Dillon, C. and Coat, M. (2001) Key Skills: making a difference. Milton Keynes: The Open University.

Holloway, J. and Francis, G., 2002, Quality in Higher Education, 8.3, pp. 239-54.

http://www.derby.ac.uk/careers/staff/bibliograph.htm

Institute of Directors (IOD), 1991, Performance and Potential: Education and Training for a Market Economy. London, Institute of Directors.

Institute of Manpower Studies (IMS), 1981, Graduate Employment and Careers. IMS Report No. 30. Sussex, IMS.

International Association for the Exchange of Students for Technical Experience (IAESTE) http://www.iaeste.org/

JEWELS, 2002, Information for Practitioners: Independent work experience modules, http://www.jewels.org.uk/practitioners.htm

Johnson, D. and Pere-Vergé, L. 1993, 'Attitudes towards graduate employment in the SME sector', International Small Business Journal, 11, no. 4, pp. 65-70.

Johnson, D., Pere-Vergé, L. and Hanage, R., 1993, 'Graduate retention and the regional economy', Entrepreneurship and Regional Development, 5, pp. 85-97.

Khawaja, S. et al., 1991, Technical Education: Its Relevance to Job Market. A Research Report. AEPAM Research Study, no. 90. Islamabad, Ministry of Education, Academy of Educational Planning and Management.

Kinman, R. and Kinman, G., 1998, “'There isn't time to stop and think in this place": organisational culture versus effective work-based learning' Local Economy Quarterly, 5(4) December, pp. 41-56

KITTS, 2002, http://www.wmg.warwick.ac.uk/SME_MTC.shtml

Knight, P. \& Yorke, M., 2002, Skills plus, Tuning the Undergraduate Curriculum, http://www.open.ac.uk/cobe/pdfDocs/docs-skill+/ANewIntroSkills.pdf

Knight, P. T. and Yorke, M. (2003, forthcoming) Employability and good learning, Teaching in Higher Education 8(1)

Knight, P. and Yorke, M. (2004) Learning, Curriculum and Employability. London: Routledge.

La Valle I., O'Regan S., Jackson C., (2000), The Art of Getting Started: Graduate skills in a fragmented labour market, http://www.employment-

studies.co.uk/summary/summary. php?id=364 
Lambert, E., Scarles, C., Marlow-Hayne, N., Blakeman, A., Morey, A. and Harvey, L., 2001, Employability and the Media Studies Curriculum, Report to a Consortium of Four Universities, July 2001. Birmingham, CRQ.

Learning and Teaching Subject Network (LTSN), 2003, Engineering site on employability, http://www.Itsneng.ac.uk/er/employability/index.asp

Learning and Teaching Subject Network (LTSN), Generic Centre, 2001, 'Enhancing student learning through voluntary work', Guide for Busy Academics No.5 October,, Available on the LTSN Generic Centre website as PPD010.

http://www.Itsn.ac.uk/application.asp?app=resources.asp\&process=full_record\&section=gene ric\&id $=70$

Learning and Teaching Support Network (LTSN) Generic Centre 2003 Learning and Employability Series of papers http://www.Itsn.ac.uk/genericcentre/for-

scs/index.asp?id=17898

Leeds Metropolitan University's Skills for Learning,

http://www.Imu.ac.uk/aqd/careers/empskill.htm

Lees, D., 2002a, Information for Academic Staff on Employability. University of Exeter. Available on the LTSN Generic Centre website as EMP007.

http://www.Itsn.ac.uk/application.asp?app=resources.asp\&process=full_record\&section=gene ric\&id=188

Lees, D., 2002b, Graduate Employability: Literature Review. Available on the LTSN Generic Centre website as EMP006,

http://www.Itsn.ac.uk/application.asp?app=resources.asp\&process=full_record\&section=gene ric\&id=190

Lees, D., 2002c, E-mail correspondence with Lee Harvey, Nov, 2002.

Lindley, R., ed., 1981, Higher Education and the Labour Market. Guildford, Society for Research into Higher Education (SRHE).

Little, B., Enhancing Student Employability Co-ordination Team (ESECT) \& Centre for Higher Education Research and Information (CHERI) at the Open University, 2003, Some International Perspectives Available on the LTSN Generic Centre website as EMP009, http://www.Itsn.ac.uk/application.asp?app=resources.asp\&process=full_record\&section=gene ric\&id $=230$

Little, B., Moon, S., Pierce, D., Harvey, L. and Marlow-Hayne, N., 2001, Nature and extent of undergraduates' work experience. London, CIHE/DFES.

Liverpool John Moore's University (JMU), 2002, Generic Topics \& Case Studies, The Skillsplus Project, 'Good learning enhances employability',

http://cwis.livjm.ac.uk/lig/ltweb/gen/case_study/20.htm

Lucas, R. and L. Ralston (1997). 'Youth, gender and part-time employment. A preliminary appraisal of student employment', Employee Relations 19(1): 51 - 66.

Mansergh, T. P., 1990, The Relationship of Occupational Skills and Attributes in Work Situations to Salary and Occupation. Armidale, NSW, M.Ed thesis, University of New England.

Mason, S. and Harvey, L., 1995, Funding Higher Education: Student Perspectives.

Birmingham, Centre for Research into Quality, University of Central England in Birmingham.

Medhat, S., 2003 'A new beginning for a strained relationship', Times Higher Education Supplement, 24 January, p. 18. 
Metcalf, H., 2001, Increasing Inequality in Higher Education: The Role of Term-Time Working, NIESR, London (Unpublished Paper).

Middlesex University, 2002, National Centre for Work-based Learning Partnerships http://www.mdx.ac.uk/www/ncwblp/

Millennium Volunteers, 2001, http://www.go-wm.gov.uk/Connexions/volunteers

Mooney, T., 2002, 'Work it out', Guardian Unlimited, 9 April.

http://education.guardian.co.uk/students/story/0,9860,681017,00.html

Napier University , 2003, Volunteering in the Community

http://www.napier.ac.uk/modular_catalogue/modules/module.asp?ModuleID=CP22001

National Board of Employment, Education and Training (NBEET), 1992, Skills Required of Graduates: One Test of Quality in Australian Higher Education. Canberra, Australian Government Publishing Service. (Also referred to as Skills Sought by Employers of Graduates on front cover of published report).

National Centre for Work Experience (NCWE), 2002, Work Related Learning Report. February. Nottingham, DfES.

National Committee of Inquiry into Higher Education (NCIHE), 1997, Higher Education in the Learning Society. London, HMSO.

National Council for Work Experience (NCWE), 2002, Welcome to the National Council for Work Experience http://www.work-experience.org

National Union of Students (NUS), 1999, Student Hardship Survey, NUS Publishing, London

National Union of Students (NUS), 2002, National Skills Learning Programme

http://www.nusonline.co.uk/nslp/

Newell, C., and Winn, S., 2000, The financial situation of students at the University of Brighton: the ninth report, 1999/2000 Health and Social Policy Research Centre, University of Brighton, Brighton

O'Leary, J., 1981, 'A crisis of our own manufacturing', Times Higher Education Supplement, No. 450 , p. 8.

Oakey, D., Doyle, M. \& Smith, J., 2000, A Strategic approach to undergraduate key skills development: Salford key skills project, final report. University of Salford.

Oakland, R., 2002, Directory of Employability Resources: Information for academic staff in higher education in the UK who wish to enhance their students' preparedness for work. York, LTSN Generic Centre. Available on the LTSN Generic Centre website as EMP001

http://www.Itsn.ac.uk/application.asp?app=resources.asp\&process=full_record\&section=gene ric\&id=165

Oxford Brookes University, 2002, The Ability Based Curriculum (ABC) network, http://www.brookes.ac.uk/services/ocsd/6_archive/abc/abchome.html

Park and The Guardian, 2002, Graduates in the Eyes of Employers, 2002, London, Park/Guardian. Further information from sufia.hussain@parkhr.com

Paton-Saltzberg, R. and Lindsay, R.O., 1995, The Effects of Paid Employment on the Academic Performance of Full-time Students in Higher Education. A report of a study commissioned by the Academic Standards Committee of Oxford Brookes University. Oxford, Oxford Brookes University. 
Pearson, R., 1976, Qualified Manpower in Employment. Sussex, Institute of Manpower Studies (IMS).

Phillips-Kerr, B., 1991, A Survey of Careers Destinations: 1985 Modern Language Graduates of the Universities of Bradford, Hull, Newcastle Upon Tyne, Sheffield and the Polytechnic of Newcastle Upon Tyne. Newcastle, University of Newcastle Careers Advisory Service, May.

PlaceNet, 2003, http://www. placenet.org.uk/index.htm

Policy Studies Institute (PSI), 1990, Britain's Real Skills Shortage. January, London, PSI.

Prospects Planner, 2003, Welcome to Prospects Planner

http://www.prospects.ac.uk/cms/ShowPage/Home_page/What_job_would_suit_me_ Prospe cts_Planner_Prospects_Planner/p!emepX

Purcell, K., Pitcher, J. and Simm, C., 1999, Working Out? Graduates' early experience of the Labour Market. Manchester, CSU.

Quality Assurance Agency (QAA), date, Code of Practice on Placement Learning http://www.qaa.ac.uk/public/cop/COPplacementFinal/PlacementLearning.pdf

Quality Assurance Agency for Higher Education (QAA), 2001, 'Guidelines for HE Progress Files', http://www.qaa.ac.uk/crntwork/progfileHE/guidelines/progfile2001.pdf

Quality Assurance Agency for Higher Education (QAA), 2002, 'What is a Progress File?' http://www.qaa.ac.uk/crntwork/progfilehe/contents.htm

Quality Assurance Agency for Higher Education and the Engineering Professors' Council (QAA/EPC), 2002, Report of a Quality Assurance Agency for Higher Education and Engineering Professors' Council joint working group on the compatibility between the QAA Subject benchmark statement for Engineering and the EPC Engineering Graduate Output Standard. Gloucester, QAA.

http://www.qaa.ac.uk/crntwork/benchmark/mast/compat\%2Depc\%2Doutput.htm

Loughborough University, 2002, RAPID project (with partners at UCE) and the RAPID Progress File. http://rapid.Iboro.ac.uk/

Ratcliff, J. L. and associates, 1995, Realizing the Potential: improving postsecondary teaching, learning and assessment. Pennsylvania: National Center on Postsecondary Teaching, Learning and Assessment.

Reed Executive, 2001, British Firms Rate Voluntary Work, Band and Brown

Richardson, D. M., 1989, Perceptions of Employers of Northern Alberta Institute of Technology (NAIT) Marketing Management Graduates: A Follow-up Study. M.Ed. Thesis, University of Alberta.

Rover Group, 1998, Young People Development Survey, 1997, unpublished report.

Salford University, 2000, Salford Key Skills Project, http://www.salford.ac.uk/studentinfo/undergrads/key.shtml

Sewell, P., 2001, 'Higher Level Skills in Creative Industries in Lancashire \& Cumbria' LMI Briefing, 26, July. North West Labour Market Partnership.

http://www.Imi4he.ac.uk/Documents/Brief26.doc

Sheffield Hallam University (SHU) 2002, Introduction of Blackboard http://elearning.shu.ac.uk/blackboard/bb_faqs/ 
Sheffield Hallam University (SHU) 2003, Student employment initiative sets out its stall http://www.shu.ac.uk/cgi-bin/gnews_full.pl?id_num=PR363

Sheffield Plus, 2002, http://www.cyberws.co.uk/plus/

Skills Task Force 1998, 'Towards a National Skills Agenda: First report of the National Skills Task Force. Sudbury, Suffolk, Prolog.

Skills, Knowledge and Organisational Performance (SKOPE), 2003, http://www.economics.ox.ac.uk/SKOPE

Smith, N. and P. Taylor, 1999, 'Not for lipstick and lager: students and part-time work', Scottish Affairs Journal 28(Summer): 147 - 163.

Southampton Institute, 2002, http://www.blackandasiangrad.ac.uk/about/southampton.asp

Speakman, Z., Drake, K and Hawkins, P., 2001, The Art of Crazy Paving, Student Volunteering UK: DfES Publications.

STADIA, 2003, Project Case Study Search http://usitweb.shef.ac.uk/ stadia/accred.html

STEP 2002a, Skills online http://www.skills-online.co.uk/apps/student/content.asp

STEP 2002b, 'Danielle Holden walks away with top award in UK's toughest student competition', Press Release, 18 October http://www.step.org.uk/

STEP, 2003, STEP Website, http://www.step.org.uk/

Student Volunteering UK, 2003, http://www.studentvol.org.uk/

SVBangor, 2003, Student Volunteering Bangor http://www.undeb.bangor.ac.uk/svbangor/eng/

Taylor, N. K., 1998, 'Survey of paid employment undertaken by full-time undergraduates at an established Scottish university', Journal of Further and Higher Education 22(1): 33-40.

TCS, 2003, Brining people together http://www.tcsonline.org.uk/

Teichler, U., 1989, 'Research on higher education and work in Europe', European Journal of Education, 24, no. 3, pp. 223-47.

Teichler, U., 1998, 'Higher education and the world of work: Changing conditions and challenges', paper for the UNESCO World Conference on Higher Education, Paris.

Times Higher Education Supplement (THES), 1998, Part-time working 'can harm studies', 23 January, 1998.

Trades Union Congress (TUC), 1989, Skills 2000. London, TUC.

UEA Skills Website, (2003), The Skills Site: The art of doing http://www.skills.uea.ac.uk/

Unite/Mori , 2000, Student Living Report Unite, Bristol

Universities UK/SCOP, 2002, Student Services: Effective approaches to retaining students in higher education London, UniversitiesUK

http://www.universitiesuk.ac.uk/bookshop/HowToOrder.asp?Code=127

University College Chester. 2002, New centre designed to meet the needs of businesses in Cheshire http://www.chester.ac.uk/alumni/2000/collegenow5.html 
University of Nottingham, 2002, Recording achievement case study

http://www.recordingachievement.org/case_studies/cs_detail.asp?sid=58

University of Birmingham, 2002, Continuing professional development Report of the Workbased learning group. Limited access

http://www.ao.bham.ac.uk/aps/cttees/docs/paper.asp?p=AB.02.10.05(a)

University of Bournemouth, 2003, Curriculum Vitae Guidelines

http://www.bournemouth.ac.uk/careers/html/workshops.htm

http://www.bournemouth.ac.uk/careers/html/curriculum_vitae.htm

University of Bradford, 1998-2000, Key skills project

http://www.bradford.ac.uk/admin/studev/html/keyskills.htm

University of Bradford, 2002, Excellence Plus, http://www.bradford.ac.uk/excellenceplus/

University of Bradford, 2002, Excellence Plus: Developing key skills for the future, has brief details on the 'Career and personal development module'

http://www.bradford.ac.uk/excellenceplus/future.php

University of Bradford, 2002, IMPACT, http://www.bradford.ac.uk/admin/impact/

University of Bradford, 2003, Insight Plus http://www.insightplus.co.uk/

University of Central England in Birmingham (UCE) Careers Service, 2002, Delivering Employability: A Framework for Career Development in the Curriculum, Birmingham, UCE, http://www.ssv.uce.ac.uk/Careers/car-staff-employ-deliver.htm

University of Central England in Birmingham, Careers @ UCE, 2003, Delivering Employability: A Framework for Career Development in the Curriculum http://www.ssv.uce.ac.uk/Careers/car-staff-employ-deliver.htm

University of Derby, 1999, Career Management Network. A DfEE Discipline Network project, http://www.derby.ac.uk/careers/cmn/manage.htm

University of Durham, 2002, Foundation for SME Development, http://www.graduatesforgrowth.org.uk/graduates/

University of East Anglia (UEA), 2003, 'Personal and professional development for Scientists'. http://www.uea.ac.uk/che/ppds/

University of East Anglia (UEA), 2003, EmployAbility

http://www.uea.ac.uk/ccen/employability/students/use.shtml

University of East Anglia (UEA), 2003, Learning through Earning, a DfEE Work Experience project, (1997-2000) Final report http://www.dfes.gov.uk/dfee/heqe/we_eastanglia.doc

University of East Anglia (UEA), 2003, UEA Matrix, http://www.skills.uea.ac.uk/matrix/

University of East London (UEL), 2001, Getting your degree to work. ED320 Work-based Learning Level 1 (Elective) Unit Guide and Student Workbook, 2001-2002. London, UEL. See latest News on this at http://www.uel.ac.uk/news/latest_news/stories/summer_work.htm

University of Glamorgan 2002, Experience Works project http://www.glam.ac.uk/careers/experience/experienceworks.php http://www.universitiesuk.ac.uk/bookshop/downloads/employability.pdf

University of Liverpool 2002, Voluntary Service Learning module http://www.universitiesuk.ac.uk/bookshop/downloads/employability.pdf 
University of Luton, 2003, Work-based Learning Opportunities

http://www.luton.ac.uk/studentresources/wbl.shtml

University of Manchester Careers Service, 2002, Career Management Skills Programme 2002-3, http://www.cs.man.ac.uk/Study_subweb/Ugrad/IndPlace/Programme_2002.html

University of Newcastle, 2001, Careers Advice http://www.ncl.ac.uk/student-

support/postgrad/careers.html

University of Newcastle, 2002, Business Enterprise module.

http://www.universitiesuk.ac.uk/bookshop/downloads/employability.pdf

University of North London (UNL), 2002, BSc Applied Consumer Psychology

http://www.universitiesuk.ac.uk/bookshop/downloads/employability.pdf

University of Portsmouth, 2002, Independent Learning Career Management Skills.

http://www.recordingachievement.org/downloads/100112.pdf

University of Reading, 2002, Career management, case study

http://www.universitiesuk.ac.uk/bookshop/downloads/employability.pdf

University of Sussex, 2002, Schools and Colleges Liaison Service: Widening participation, Sussex Coastal Highway, http://www.sussex.ac.uk/Units/schoolsliaison/participation/ see also http://www.ussu.net/activities/volunteer/sussexcostalhigh/index.shtml

University of Wales Institute Cardiff, 2001, Work Experience and Employability Plan forming part of the Learning and Teaching Strategy 2000-2003 Revision September 2001 http://www.uwic.ac.uk/uwicnet/studserv/S_UWICstaff/WEEP.doc

University of Wales, Aberystwyth 2002, Year in Employment Scheme http://www.aber.ac.uk/careers/yes/ and http://www.Ilwybroroutes.co.uk/english/opportunities/students/year_employ.php

University of Wales, Bangor 2002, Peer Guiding

http://www.bangor.ac.uk/careers/students/peerguiding see also

http://www.bangor.ac.uk/news/Peer.htm

University of Westminster Business School, 2003 'Learning from work module' http://www.wmin.ac.uk/marylebone/wbs/modules_pdf/4HRB506.pdf

University Wales Institute Cardiff (UWIC), 2003, Research on Benefits of Work Experience http://www.uwic.ac.uk/uwicnet/studserv/workplacement/research_on_benefits_of_work_exper ience.htm

Walker, L., 1999, "Longitudinal study of drop-out and continuing students who attended the Pre-University Summer School at the University of Glasgow." International Journal of Lifelong Education 18(3): 217 - 233.

Ward, R. and Pierce, D. (Centre for Recording Achievement), with advice from ESECT, LTSN Generic Centre colleagues and guidance practitioners, 2003, Employability and students' educational experiences before entering higher education Available on the LTSN Generic Centre website as EMPL010

http://www.ltsn.ac.uk/application.asp?app=resources.asp\&process=full_record\&section=generic\&id=2 34

Weller, G., 1994, Report of the Work Based Learning Project 1993-94 University of

Wingrove, J. and Herriot, P., 1984a, 'Graduate pre-selection: some findings and their guidance implications', British Journal of Guidance Counselling, 12, no. 2, pp. 166-74. 
Wingrove, J. and Herriot, P., 1984b, 'Decision in graduate pre-selection', Journal of Occupational Psychology, 57, no. 4, pp. 269-75.

Woodcock, B. 2003, Summary of PDP development activity undertaken resulted in him posting following an anonymised e-mail enquiry. Careers Advisory Service, University of Kent at Canterbury.

Work Experience Bank, 1998 Students' Work: a study of the work experience of students. Sheffield, DfEE. 